\title{
Los tratados de agricultura como fuente para el estudio de la propiedad aristocrática andalusí*
}

\section{Agricultural Treatises as Sources for the Study of Andalusi Aristocratic Property}

\author{
Pedro Jiménez-Castillo \\ Escuela de Estudios Árabes, CSIC \\ ORCID iD: https://orcid.org/0000-0002-6012-4414 \\ Inmaculada Camarero \\ Escuela de Estudios Árabes, CSIC \\ ORCID iD: https://orcid.org/0000-0003-0197-9460
}

\begin{abstract}
Resumen
El conjunto de tratados de agricultura que se elaboró en al-Andalus ha sido hasta ahora explotado como fuente para aspectos relacionados con la botánica y la historia de las técnicas agrícolas; sin embargo, se ha empleado poco para la obtención de información histórica, aspecto que hemos tratado de enfatizar en este trabajo. Con este objetivo, hemos intentado situar la eclosión de los libros de agricultura en su contexto histórico: el de la revolución económica y demográfica plenomedieval, uno de cuyos aspectos más significativos fue la expansión agrícola impulsada por un estamento de terratenientes, muchos de ellos residentes en las ciudades, que puso en marcha una producción orientada básicamente al mercado. A este grupo social es al que creemos estaban destinados principalmente los libros geopónicos, pues tenía la necesidad y los recursos económicos e intelectuales para aprovecharlos, a diferencia de los pequeños propietarios y las comunidades gentilicias de campesinos que practicaban una agricultura destinada esencialmente al autoabastecimiento. Una vez que reconocemos los libros de agricultura como auténticos manuales de aquellos hacendados, se puede recuperar esa literatura como fuente histórica de primer orden con el fin de conocer el funcionamiento y la organización de ese tipo de propiedad fundiaria en esta fase de la historia de al-Andalus.
\end{abstract}

Palabras clave: agricultura de al-Andalus; almunia; bustān; finca rústica; tratados de agricultura.

\begin{abstract}
The set of agricultural treaties that were drawn up in al-Andalus has been exploited so far as a source for aspects related to botany and the history of agricultural techniques; however, it has been little used as a historical source, which we have tried to emphasize in this article. To this end, we have tried to place the eclosion of agricultural books in their historical context: that of the High Middle Ages economic and demographic revolution, one of whose most significant aspects was the agricultural expansion driven by a landowning urban aristocracy that launched a production oriented basically to the market. It is precisely this privileged class that was interested in geoponic books and had the resources and training to take advantage of them, as we have tried to demonstrate. Once we recognize the agricultural books as authentic manuals of these landowners, that literature can be recovered as a first-rate historical source to know about the operation and organization of the land ownership of the Andalusian aristocracy.
\end{abstract}

Key words: agriculture of al-Andalus; almunia; bustān; country estate, agriculture treaties.

Cómo citar / Citation: Jiménez-Castillo, Pedro y Camarero, Inmaculada, "Los tratados de agricultura como fuente para el estudio de la propiedad aristocrática andalusí”, Al-Qanțara, 42, 1 (2021), e01. doi: https://oi.org/10.3989/ alqantara.2021.001.

Recibido: 11/11/2019; Aceptado: 04/06/2020; Publicado: 02/07/2021

* Este trabajo se ha realizado en el marco del proyecto ALMEDIMED “Almunias medievales en el Mediterráneo: Historia y conservación de los paisajes culturales periurbanos" (PID2019-111508GBI00), del que es IP el Dr. Julio Navarro (EEACSIC). Cofinanciado con fondos FEDER, pertenece al Programa Estatal de Generación de Conocimiento y Fortalecimiento Científico y Tecnológico del Sistema de I+D+i, Subprograma Estatal de Generación del Conocimiento, del Ministerio de Ciencia e Innovación. Sin la contribución de los colegas de este proyecto durante los últimos años, este trabajo no habría sido po- 


\section{Introducción}

El objetivo general de este trabajo es el de enfatizar el valor de los tratados geopónicos andalusíes como una fuente histórica de primer orden, más allá de su indiscutido interés para el estudio de disciplinas y materias específicas, como la historia de las técnicas agrícolas o la botánica. Para ello, trataremos de indagar sobre un aspecto crucial en este sentido y, sin embargo, poco discutido en la historiografía, como es el de la finalidad y los destinatarios de dichas obras. Este análisis nos va a permitir plantear la hipótesis de que fueron escritas para propietarios de tierras con la formación y los recursos suficientes para tener acceso a unos libros que les servían de manuales para la gestión de sus propiedades fundiarias $\mathrm{y}$, en consecuencia, que proporcionan datos históricos valiosos sobre el funcionamiento y la organización del trabajo en las fincas de las élites, en el contexto de un proceso, bien situado en el tiempo, de expansión de la agricultura orientada al mercado y de desarrollo económico en general.

Antes de comenzar con el estudio, creemos imprescindible adelantar unas consideraciones en relación con la nomenclatura que nos encontramos recurrentemente en los libros de agricultura para designar a las propiedades fundiarias. En esta literatura, como en general sucede en los textos andalusíes, se pueden registrar diferentes palabras para nombrar realidades aparentemente similares y, por otra parte, dichos términos son marcadamente polisémicos. El nombre que aparece más frecuentemente en los libros de agricultura para denominar las fincas de las que se ocupan es el de bustān, pl. basātīn, identificado normalmente como huerto o como jardín, mientras que es mucho menos frecuente munya, palabra de la que deriva la castellana «almunia» ${ }^{1}$. Este último término, muy utilizado

sible, por lo que deseamos expresar nuestro reconocimiento a todos ellos, y en particular al IP del mismo. También damos las gracias a los dos revisores anónimos del borrador del artículo, así como al consejo de redacción de la revista, puesto que sus numerosas correcciones y sugerencias han contribuido notablemente a mejorar el texto final. Y, por último, no nos queremos olvidar del personal de la Biblioteca de la Escuela de Estudios Árabes, por la ayuda obtenida en la localización y acceso de las fuentes árabes que les hemos solicitado.

Efectivamente, este término es citado por al-Ṭignarī solo una vez y en su plural munà, con relación a los emparrados que se arman en las almunias. Véase, Kitāb zuhrat al-bustān, pp. 343-344. Véase, además, García Sánchez, "Terminología y funcionalidad de las almunias andalusíes", pp. 17-25. en al-Andalus según demuestran no solo los textos árabes sino también la toponimia e incluso la documentación latina y romance posterior a la conquista ${ }^{2}$, denominaba a unas explotaciones agrícolas que comprendían también casas de campo destinadas al recreo de sus propietarios, definición que conviene, por otro lado, con el bustān ideal descrito por Ibn Luyūn en su tratado de agricultura, como veremos más adelante. Es decir, en algunas de sus acepciones, bustān y munya podían ser sinónimos, según demostró Expiración García ${ }^{3}$; por consiguiente, cuando en los tratados de agricultura se hace mención a un bustān, puede referirse sencillamente a un huerto o bien a una almunia con las características que antes explicamos.

Pero los libros de agricultura, y los textos árabes en general, recogen otros términos para definir a estas fincas agropecuarias, debido seguramente a la diversidad de funciones (agrícolas, ganaderas, residenciales, protocolarias, recreativas) que en ellas se podían dar. Los más

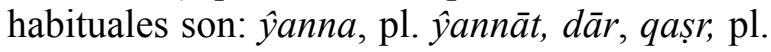
qușūr, karm, pl. kurūm, huš̌s, hà 'iț, ha'ir / hayr, buhayra, nā'iùra y riyāẹ. Los límites de bustān y ýanna tampoco están claros ${ }^{4}$, pues depende del contexto en el que se hallen. Ŷanna en ocasiones es sustituida por el singular ŷinān, propio del árabe granadino; dār hace alusión a cualquier tipo de casa o vivienda ${ }^{5}$; qașr, pl. qușūr, que significa palacio o alcázar; karm, pl. kurūm, comúnmente es viña, viñedo ${ }^{6}$, hušš hace referencia a un jardín o vergel; $h \bar{a}$ 'it es, la mayoría de las veces, un huerto cercado con muros; $h \bar{a}$ 'ir / hayr es un jardín o bien un depósito de agua; buhayra, diminutivo de bahr (mar), se refiere comúnmente a un lago o a una alberca; nā' ūra

Sénac, "De la madîna à l'almunia", pp. 183-201; Eritja i Ciuró, De l'Almunia a la Turris, passim; Ramón-Laca Menéndez de Luarca, "Almunias en los reinos de Castilla y Aragón”, pp. 443-451.

García Sánchez, "Cultivos y espacios agrícolas irrigados en al-Andalus", p. 20.

4 Además de ser ŷanna y bustān prácticamente sinónimos, en ocasiones aparecen juntos, lo que puede deberse a un recurso estilístico, por lo que no habría realmente ninguna diferencia entre ellos. Véase para ello, García Sánchez, "Cultivos y espacios agrícolas irrigados en al-Andalus”, pp. 17-18 y $22-26$.

Navarro Palazón y Jiménez Castillo, "El Alcázar Menor de Murcia", pp. 150-151.

6 Como las que rodean a las murallas de la Granada nazarí o las que riega la acequia de Aynadamar por la zona norte de la ciudad. Véase, por ejemplo, Ibn al-Jațīb, Al-Ihạța, ed. B. Derradji, I, p. 221; ed. 'Inān, I, p. 120. 
significa noria y rawd, pl. riyāẹ, jardín, vergel ${ }^{7}$. En los textos posteriores a la conquista cristiana, aparecen documentados con el sentido de finca privada los términos real (derivado de riyāẹ) que designa propiedades periurbanas de regadío, y rahal, que identifica explotaciones predominantemente de secano ${ }^{8}$.

De manera convencional, hemos optado por utilizar aquí el término «almunia» para hacer referencia al tipo de propiedad fundiaria y recreativa antes descrita, por ser el vocablo más apropiado en el castellano actual para definir esa realidad. No obstante, en las traducciones nos hemos limitado a emplearlo cuando el original árabe era munya y, en cualquier caso, siempre hemos acompañado nuestras interpretaciones con el vocablo árabe original.

\section{Los tratados de agricultura y los calendarios andalusíes}

A partir del s. X, un círculo de médicos, farmacólogos y botánicos vinculados a la corte cordobesa, se agrupó alrededor de la figura del médico Abū l-Qāsim Jalaf b. 'Abbās alZahrāwī (s. X-XI) ${ }^{9}$, ocupándose, además, de otras ciencias relacionadas, como era la agronomía ${ }^{10}$. Pero fue en el siglo XI cuando esta disciplina alcanzó su máximo esplendor, tanto en lo práctico como en lo teórico, dando lugar a una importante literatura geopónica, que ha permitido que algunos estudiosos hablen de la «escuela agronómica andalusí». Efectivamente, es en este siglo cuando un grupo de agrónomos «frecuentaron los mismos círculos intelectuales y crearon unos vínculos de transmisión del saber, a través de los cuales podemos establecer el concepto de escuela con una relación directa entre maestros y discípulos» ${ }^{11}$. Ellos formaron una verdadera comunidad científica, utilizando las mismas herramientas de análisis y compartiendo una visión similar del mundo ${ }^{12}$.

\footnotetext{
7 Véase, por ejemplo, Navarro Palazón y Puerta Vílchez, "Las huertas de Marrakech", pp. 285-322.

8 Jiménez Castillo, "Fincas aristocráticas en la Murcia islámica", pp. 749-791; Jiménez Castillo, "Reales y rahales de la Murcia andalusí”, pp. 389-436.

9 Conocido como Abulcasis o Albucasis entre los latinos.

10 Véase más de este personaje y su influencia en el nacimiento de la ciencia agronómica andalusí en Álvarez de Morales, “Agrónomos andalusíes y sus legados", pp. 24-25.

11 García Sánchez, "Ibn al- Awwām, Abū Zakarīyā”", p. 448.

12 El-Faïz, "L'apport des agronomes d'al-Andalus”, p. 55.
}

Estos geóponos bebieron de fuentes orientales, las cuales a su vez habían recogido previamente la tradición clásica; las principales, según citan los propios tratados agrícolas andalusíes, son: Filāḥa rūmiyya o Filāḥa yūnāniyya, atribuida a Qusțus; la Agricultura Nabatea, obra traducida al árabe por Ibn Wahšiyya en el siglo $\mathrm{X}$ a partir de materiales siríacos que se remontan a los siglos III-V d.C.; y la compilación anónima realizada en el s. X y dedicada al emperador bizantino Constantino VII, que conocemos como los Geoponica. El ascendiente oriental de las obras andalusíes no les resta valor alguno como fuente de conocimiento histórico para el periodo en que fueron compuestas, puesto que, más allá de la inspiración y de la información recuperada de los antiguos, la propia opción por este tipo de literatura en este preciso momento tiene un significado que solo se puede interpretar adecuadamente en su contexto socioeconómico. Además, los autores hispanoárabes aprovecharon la geoponimia clásica sin actuar como meros editores o traductores de la misma. Efectivamente, existen diferencias notables entre ambas tradiciones, puesto que los andalusíes incorporaron sus propias experiencias y desecharon todo aquello que no consideraban de utilidad, de manera que sus libros reflejan un interés más elevado con relación a lo práctico y experimental que sus antecesores, rechazando lo mágico y supersticioso presente, sobre todo, en la Agricultura Nabatea ${ }^{13}$. Esto demuestra, en última instancia, el carácter pragmático y la intención utilitaria de la literatura agrícola en general a lo largo de la historia, desde la Antigüedad a la Edad Moderna, y en particular de la hispanoárabe.

Los tratados de agricultura andalusíes, tal y como lo hacían tradicionalmente las fuentes de donde parten ${ }^{14}$, suelen comenzar describiendo los tipos de tierra, la manera de modificarla y prepararla para su siembra a través, entre otras labores, de la nivelación y roturación. Posteriormente, se habla de los tipos de aguas y de abonos, según la tierra de la que se trate, de lo que se quiera plantar o del tiempo en el que se desee sembrar. Precisamente, una de las principales aportaciones de la agronomía en el siglo XI es la creación de una auténtica ciencia pedológica

13 Carabaza Bravo, "El agua en los tratados agronómicos andalusíes", pp. 19-38; García Sánchez, "Las fuentes citadas en el tratado agrícola de al-Ṭignarî”, pp. 205-231; Fahd, "L'agriculture nabatéenne en Andalousie", pp. 41-51.

14 Carabaza Bravo, "El agua en los tratados agronómicos andalusíes", p. 21. 
destinada al acondicionamiento y mejoramiento de los suelos, de manera que no solo permitía aumentar el rendimiento de las áreas cultivadas sino la colonización y puesta en explotación de otras tierras yermas que antes habrían sido consideradas como incultivables ${ }^{15}$.

Seguidamente, los vegetales se analizan por grupos y se especifican diversas labores como su modo de siembra, abono, cultivo, injerto, poda y demás faenas. Algunos de los autores también ahondan en las cualidades que esos productos poseen para la alimentación, así como las recetas culinarias que se pueden realizar con ellos. No se olvidan de tratar el tema de las plagas, del cuidado que se ha de proporcionar a los cultivos durante su desarrollo y del mejor modo y momento para la cosecha. Interesantes también son las páginas dedicadas a la conservación de las especies vegetales ${ }^{16} \mathrm{o}$ a la cría de animales para su explotación ${ }^{17}$. En general, destacan por ser obras teóricas pero con una fuerte base experimental, de manera que sus autores suelen incluir en sus textos la expresión de «yo mismo he visto», «yo ya lo he experimentado y es cierto» o «esto es algo ya experimentado y es verídico».

Dentro de los tratados de agricultura, el más temprano es el titulado Kitāb fì tartīb awqāt al-girāsa wa-l-magrūsāt (Libro del ordenamiento de los tiempos de la plantación y de los plantíos), de la segunda mitad del s. X y principios del s. $\mathrm{XI}^{18}$. Actualmente, se considera bastante probable que su autor sea el andalusí Ibn Abī l-Ŷawād, de origen cristiano, mozárabe o muladí, y que este hubiera vivido en la Córdoba omeya justo cuando se inició la época de mayor esplendor cultural ${ }^{19}$. Esta obra depende de las tradiciones orientales y casi no habla con voz propia. Tampoco se ocupa de asuntos tan importantes como las aguas, las tierras, los estiércoles o los cereales; no alude al calendario agrícola ni

\footnotetext{
15 Bolens, "La révolution agricole andalouse", pp. 124 125.

16 Véase, para ello, García Sánchez, "La conservación de los productos vegetales", pp. 251-293.

17 Consúltese, por ejemplo, Carabaza Bravo, "Las palomas en la agricultura andalusí", pp. 233-256.

18 Kitāo fì tartīb awqāt al-girāsa wa-l-magrusāt. Un tratado agrícola andalusí anónimo, ed. y trad. Ángel Custodio López y López, Granada, 1990.

19 Una nota marginal en el tratado de Ibn Luyūn señala que la obra de este autor tiene por título Kitāb al-Filāha. Puede suponerse, pues, que el título por el que se conoce esta obra, Kitāb fì tartīb awqāt al-girāsa wa-l-magrūsāt, ofrecido por el manuscrito tunecino, haya tomado el nombre de su primer capítulo. Véase, López y López, "Ibn Abī 1-Ŷawād", pp. 753-755.
}

tiene sección dedicada a la veterinaria. De todas formas, es conocido por los geóponos posteriores, los cuales en ocasiones citan en sus obras párrafos idénticos ${ }^{20}$. De los diez capítulos en los que se divide esta obra, López y López destaca el quinto, dedicado al cultivo de las principales plantas ornamentales conocidas hasta la fecha, por lo que constituye el primer documento sobre la plantación de jardines en al-Andalus ${ }^{21}$.

En cuanto a los calendarios agrícolas andalusíes, que fueron fuente continua de información de los tratados posteriores, se encuentran: el Kitāb al-anwā' wa-l-azmina -al-qawl fì l-šu$h \bar{u} r$-, de Ibn 'Āșim (s. XI) ${ }^{22}$; el Calendario de Córdoba, de 'Arīb b. Sa īd (s. X) ${ }^{23}$ y la Risāla fi awqāt al-sana, de autor anónimo, muy posiblemente redactada en algún momento del siglo XIII ${ }^{24}$. Los tres tratan aspectos comunes, como el nombre de los meses en el sistema solar; el número y la definición del mes en cuestión ${ }^{25}$; temas como la magia, pronósticos del tiempo, información astronómica y meteorológica; calendario de fiestas religiosas e informaciones de tipo agrícola y zoológico. No obstante, el calendario anónimo ofrece algunas diferencias con respecto a los otros tres, pues se observan en la Risāla fì awqāt al-sana algunas novedades y la inclusión de un tipo de información relacionada con la producción, que está más acorde con su uso por parte de la élite terrateniente que de «campesinos sencillos y crédulos», como señala su traductora ${ }^{26}$. El hecho de que el calendario

20 De todas formas, como apunta López y López «su relación con las demás obras agronómicas andalusíes es compleja, y entraña no poca dificultad hablar de ello con un mínimum de seguridad en las afirmaciones, pues los autores copian los textos unos de otros sin precisar su origen» ("Ibn Abī l-Ŷawād", p. 755).

${ }_{21}$ El único rasgo original en la obra es cuando cita los nombres con los que son conocidas en al-Andalus algunas plantas que crecen en los jardines, como el junquillo blanco (al-nisrīn), el lirio blanco (al-nīlūfar) y el alhelí (al-nam$m \bar{a} m$ ). Véase para ello López y López, "Ibn Abī l-Ŷawād", p. 754.

22 Ibn 'Āṣim, Kitāb al-anwā' wa-l-azmina -al-qawl fì l-šuhür- (tratado sobre los anwā' y los tiempos-capitulo sobre los meses), est., trad. y ed. crítica por M. Forcada, CSIC / ICMA, Madrid, 1993.

${ }_{23}$ 'Arīb b. Sa īid, Le Calendrier du Cordoue, publ. R. Dozy con trad. fr. anot. Ch. Pellat, E. J. Brill, Leiden, 1961.

${ }^{24}$ Risāla fì awqāt al-sana. Un calendario anónimo andalusí, ed. y trad. M. ${ }^{\text {a }}$ A. Navarro, CSIC, Granada, 1990.

25 La definición del mes incluye: el número de días, el signo del zodíaco, las mansiones del mes, el planeta que lo rige, las características de este, la estación a la que pertenece, entre otros aspectos.

26 Risāla fì awqāt al-sana, p. 23. 
anónimo sea relativamente tardío (s. XIII), posterior a la mayoría de los tratados geopónicos redactados en al-Andalus, le permitió hacerse eco del saber recogido en estos; así lo explica el autor en la presentación de su obra, después de señalar los temas que va a abordar en ella ${ }^{27}$ :

También se menciona en esta obra aquello que la gente no debe ignorar sobre los tiempos de la siembra y de la plantación, los muchos cuidados que requiere la maduración de la fruta, la época en que paren los animales y otras cuestiones según la opinión de los agrónomos ('alà madhab ahl al-filāha).

De su contenido se desprende que estaba destinado a auxiliar a los agricultores en la explotación de sus fincas, dada la enumeración exhaustiva de las labores agrícolas que debían realizarse en cada mes y las informaciones de carácter administrativo que la acompañan, tal y como lo hacen los kutub al-filäha.

Por lo que se refiere a los tratados de agricultura, son seis las obras que vamos a considerar en este estudio como fuente fundamental para el conocimiento de las propiedades aristocráticas. Sus autores son llamados de múltiples y variadas formas, entre las que se encuentran: fallāhūna (lit. «agricultores»), așhāb al-filāha (lit. «hombres de la agricultura»), ahl al-filăha (lit. «gente de agricultura») $\mathrm{y}$, como señalábamos más arriba, mahara fi l-filāha ${ }^{28}$ (lit. «expertos en agricultura»). Todos estos apelativos aluden en este contexto a su categoría de «geóponos», es decir, hombres de gran conocimiento y experiencia en las ciencias agrícolas. Son los siguientes:

Ibn Wāfid (1007/8-1074/5) escribió una obra llamada Maŷmū' fì l-filāha (Compendio de agricultura) cuya autoría, sin embargo, es objeto de discusión entre los investigadores ${ }^{29}$. El soberano al-Ma'mūn Ibn Di 1-Nūn de Toledo (1043-1075)

27 Risāla fì awquāt al-sana, pp. 35 ár. / 151-152 trad.

28 Ibn Haŷŷây, al-Muqni fí l-filāha, pp. 293 tr. / 94 ár.

29 Véase para ello, Carabaza Bravo, "La edición jordana de al-Muqni' de Ibn Haŷŷâŷ: Problemas en torno a su autoría", pp. 71-81; Carabaza Bravo y García Sánchez, "Estado actual y perspectivas de los estudios sobre agronomía andalusí", pp. 112-113; García Sánchez, "Problemática en torno a la autoría de algunas obras agronómicas andalusíes", pp. 333-341; Álvarez de Morales y Carabaza Bravo, "Ibn Wāfid, Abū 1-Muțarrif", pp. 567-568. Se suele considerar hasta la fecha que la obra de Ibn Wāfid está incluida dentro de la de Ibn Haŷȳâŷ, al-Muqni' fì l-filāha, concretamente en las pp. 6-84. Cuando nos refiramos a su obra, citaremos Ibn Wāfid, Compendio de Agricultura en Ibn Haŷŷâ̄ŷ, al-Muqni' fì l-filāha, ed. S. Ŷarrār y Abā Ṣafĩya, Ammān: Maŷma' al-Luga al-'Arabiyya al-Urduniyya, 1982. le encargó la creación y el mantenimiento del Bustān al-Nā' ūra o Huerta de la Noria. Lo confirma Ibn al-Abbār cuando dice en su Takmila que el geópono Ibn Wāfid: "se había encargado de la plantación de la célebre huerta (ŷnna) de este rey» ${ }^{30}$. Fue Ibn Bașsāl quien tomaría su relevo al hacerse cargo de dicha huerta, posiblemente a la muerte de aquel ${ }^{31}$. Su tratado nos interesa especialmente por los datos que aporta en referencia a la economía doméstica; por los consejos acerca de lo que hay que tener en cuenta a la hora de elegir los trabajadores y encargados de las grandes fincas; así como por las informaciones zootécnicas que ofrece. Posiblemente, su Compendio de Agricultura fue escrito antes de ocuparse del Bustān al-Nā'ūra de al-Ma'mūn, ya que no incluye en él sus opiniones personales sobre los temas que trata ${ }^{32}$.

Ibn Haŷŷâŷ (fines del s. XI, principios del s. XII) escribió el tratado titulado al-Muqni' fi l-filăha (Lo que basta saber acerca de la agricultura ${ }^{33}$. No se tienen datos de su nacimiento o muerte; solo se conoce que su obra salió a la luz en 1073-1074. Perteneciente a la aristocracia sevillana, tuvo grandes conocimientos teórico-prácticos de agronomía y fue transmisor de las opiniones de «los antiguos $»^{34}$, características estas de las que habló el mismo Ibn al- Awwām en su obra. De Ibn Bașșāl toma algunas informaciones, ya que redactó su libro con posterioridad al del geópono toledano ${ }^{35}$. Como decíamos anteriormente, su al-Muqni' fì l-filäha contiene dos tratados agrícolas diferentes, al incluir dentro de sus páginas el Compendio de Agricultura de Ibn Wāfid, por lo que solo se considera como

30 Ibn al-Abbār, al-Takmila, ed. F. Codera, VI, p. 551. En esta ocasión, como se aprecia, el autor le llama ŷanna en lugar de bustān, lo que confirmaría la sinonimia existente entre estos dos términos.

31 López y López, "Ibn Bașșāl, Abū Abd al-Lāh”, p. 568; Álvarez de Morales y Carabaza Bravo, "Ibn Wāfid, Abū 1-Muțarrif", p. 565.

32 Álvarez de Morales y Carabaza Bravo, "Ibn Wāfid, Abū 1-Muțarrif', vol. 5, p. 568.

33 Ibn Haŷŷâŷ, al-Muqni fì l-filāha, ed. S. Ŷarrār y Abā Ṣafìya, Ammān: Maŷma' al-Luga al-'Arabiyya al-Urduniyya, 1982. Para la traducción española a esta edición jordana, véase J. M. Carabaza Bravo, Aḥmad b. Muhammad b. Haŷŷâŷ al-Išbīlī: al-Muqni fì l-filāha, intr., est. y trad. con glosario (Tesis doctoral leída en 1987), Universidad de Granada, Departamento de Estudios Semíticos, Granada, 1988.

34 Ibn Haŷŷâŷ ofrece al final de su libro la lista de sus fuentes, que son manifiestamente griegas y latinas. Véase, para ello, Fahd, "Traductions en arabe d'écrits géoponiques", p. 16.

Carabaza Bravo, "Fuentes escritas y orales del tratado agrícola de Ibn Haŷŷâŷ”, pp. 90-91. 
obra de Ibn Haŷŷâŷ las cuarenta últimas páginas, aunque en origen era más extensa, según demuestran las referencias de Ibn al- 'Awwām, por lo que deberemos recurrir a la enciclopedia agrícola de este último para completarla ${ }^{36}$. Particularmente, es de nuestro interés al-Muqni ${ }^{\prime} f i$ l-filăha porque el autor sevillano refleja en ella su experiencia personal en las tierras que poseía en el Aljarafe, en las que pudo contrastar el saber heredado de las fuentes clásicas y orientales con la práctica diaria en tierras peninsulares ${ }^{37}$.

Ibn Bașsāl (n. ca. 1048) es el autor del Kitāb al-qașd wa-l-bayān (Libro del propósito y la demostración) ${ }^{38}$, que fue dedicado al rey taifa de Toledo al-Ma'mūn b. Di 1-Nūn (gob. 1043-1075), para el cual trabajó en su Bustān al-Na' 'ura seguramente continuando la tarea que comenzó Ibn Wāfid en dicha propiedad. En su tratado tomó como base los datos que le proporcionó su propia experiencia, sin haberse apoyado en fuentes antiguas, por lo que fue tachado por algunos autores como «analfabeto» o «iletrado». Fue maestro de Abū 1-Jayr al-Išbīlī y de al-Ṭignarī, quienes dieron detalles en sus obras de sus experimentos agronómicos y de los trabajos agrícolas que realizaba en la citada huerta real. En ocasiones, es Ibn al- 'Awwām quien recoge todos estos comentarios en su magna obra. En todos ellos se puede apreciar cómo sus logros son producto de la adaptación de los frutos al clima de al-Andalus y, más concretamente, al de Toledo ${ }^{39}$. Pero no solo hablan de Ibn Bașsāa los geóponos, sino también historiadores y literatos como Ibn $\mathrm{Sa}^{e} \overline{1} \mathrm{~d}$ al-Magribī, al-Hị̂āāi o Ibn Gālib, quienes rememoran su figura y su obra ${ }^{40}$. Posteriormente, y ante la inminente caída de Toledo (1085), Ibn Bașṣāl se trasladó a Sevilla, donde pasó a encargarse de la finca de al-Mu'tamid Ibn 'Abbād, conocida como Ŷannat o Hā'iṭ al-Sulțān, según confirma Abū 1-Jayr en numerosas ocasiones. Y es aquí don-

\footnotetext{
36 Carabaza Bravo, "Ibn Haŷŷâ̄y al-Lajmī, Abū 'Umar", p. 384.

37 Carabaza Bravo, "Ibn Haŷŷāŷ al-Lajmī, Abū 'Umar", p. 385 .

38 Ibn Bașșāl, Kitāb al-Qaș̣ wa-l-bayān, Libro de agricultura, ed y trad. J. M. ${ }^{\text {a }}$ Millás Vallicrosa y M. 'Azīmān. Tetuán, 1955 (ed. facs. con estudio preliminar por Expiración García Sánchez y J. Esteban Hernández Bermejo), Granada: Sierra Nevada 95, 1995.

39 López y López, "Ibn Bașșāl, Abū Adbd al-Lāh", pp. 566-568.

40 López y López, "Ibn Baṣṣāl, Abū Abd al-Lāh”, pp. 567-570.
}

de se consolidará la llamada «escuela agronómica andalusí», de la que fue maestro (šayj) indiscutible. A partir de su llegada, se le dará prioridad en ella al valor de la experiencia por encima de la teoría tradicional ${ }^{41}$. Este autor es importante para nuestro estudio por su énfasis en el método práctico y experimental adaptado a la realidad andalusí, así como por citar especies de reciente introducción, como la berenjena, el arroz o el algodón, o como el naranjo y el limonero, ambas nombradas en su tratado por primera vez en la historia de al-Andalus ${ }^{42}$.

Abū 1-Jayr al-Išbīlī (s. XI-XII), escribió el Kitāb al-Filāha (Tratado de Agricultura) ${ }^{43}$. Se le conoce asimismo por su apelativo al-Šaŷŷār «el arboricultor» o «el botánico», por ser además maestro docto en botánica. Nació en Sevilla, como indica su nisba, sin que se sepa la fecha exacta. En su Kitāb habla de la «Finca del Rey (Hā'it al-Sulțān)» de al-Mu'tamid y fue allí seguramente donde entraría en contacto con Ibn Bașsāa ${ }^{44}$. Para redactar su tratado, consultó tanto a eruditos como a hombres de campo experimentados, a lo que añadiría sus propias observaciones y experiencias en sus tierras sevillanas $^{45}$. Sus coincidencias con Ibn Wāfid e Ibn Bașșāl han dado lugar a que se cuestionara si los tres geóponos bebieron de las mismas fuentes o si Abū l-Jayr trasladó a su obra parte de los textos de aquellos ${ }^{46}$. Nos interesa su tratado, sobre todo, por el capítulo que dedica a la contratación de los trabajadores y encargados; por la información que aporta sobre las esculturas vegetales propia de los espacios ajardinados; por las plantas ornamentales de los aljibes, pozos y acequias; por los cercados de las grandes fincas, así como por los métodos que recomienda para que las hortalizas estivales puedan consumirse en el invierno.

Al-Țignarī (S. XI-XII), autor del Kitāb Zuhrat al-bustān wa-nuzhat al-adhān (Esplendor

\footnotetext{
41 López y López, "Ibn Bașṣāl, Abū Abd al-Lāh”, pp. 569-570.

${ }^{42}$ López y López, "Ibn Bașșāl, Abū Abd al-Lāh", p. 572.

${ }^{43}$ Abū l-Jayr, Kitāo al-Filāha. Tratado de agricultura, ed. y trad. Julia María Carabaza Bravo, Madrid: ICMA, 1991; Carabaza Bravo, "al-Išbīlì, Abū 1-Jayr", pp. 396-397.

44 Abū l-Jayr, Kitāb al-Filāha, pp. 60 ár. / 229 tr.; Carabaza Bravo, "al-Išbīilì, Abū 1-Jayr", pp. 395 y 397.

45 Carabaza Bravo, "al-Išbīlī, Abū l-Jayr", p. 397.

46 Carabaza Bravo, "al-Išbīlī, Abū l-Jayr”, p. 397.
} 
del jardín ${ }^{47}$ y recreo de las mentes $)^{48}$, era miembro de una familia granadina de noble linaje ára$\mathrm{be}^{49}$. No se tienen datos de su nacimiento o muerte, aunque Ibn al-Jațîb señala que aún vivía en $1087^{50}$. De Granada se trasladó a Almería, donde trabajó unos años en el Bustān al-Șumādihiyya de Mu tașim Ibn Șumādih (gob. 1054-1091), en donde llevó a cabo una serie de prácticas experimentales. De aquí pasó a Sevilla, relacionándose a partir de este momento con Ibn Bașșāl, con el que no siempre estuvo de acuerdo, según se puede apreciar en la propia obra de al-Țignarī. Tras hacer el hậŷy o peregrinación a la Meca, se instaló de nuevo en Granada donde terminó su obra agrícola, que fue ampliamente utilizada por Ibn al- 'Awwām e Ibn Luyūn ${ }^{51}$. Dedicada al príncipe almorávide de Granada Abū 1-Ṭāhir Țamīm ${ }^{52}$, el Kitāb Zuhrat al-bustān es un tratado teórico y práctico en el que el autor mezcla la tradición clásica mediterránea con la oriental $\mathrm{y}$, tras un proceso de comprobación y experimentación, la pone en práctica en suelo andalusí ${ }^{53}$. Hemos utilizado ampliamente a este geópono en nuestro trabajo, ya que nos da detalles de aspectos tan importantes como dónde construir las aceñas y los zafariches en las grandes fincas; lo que hay que tener en cuenta a la hora de elegir los trabajadores y los encargados de estas propiedades; de lo perjudicial que es contratar para labrar las fincas gente poco experimentada, como jóvenes o niños; cuáles son algunas de las plantas que embellecen los zafariches; el modo de armar los parrales en las almunias (munà) y, por último, la práctica industrial agrícola que se desarrollaba en los siglos XI- XII en tierras andalusíes.

\footnotetext{
47 Teniendo en cuenta el contenido de los libros de agricultura andalusíes en general y de este en particular, sería más correcto traducir bustān, en este contexto, como «huerta» o, incluso, «almunia».

48 Al Țignarī, Kitāb Zuhrat al-bustān wa-nuzhat aladhān: Esplendor del jardin y recreo de las mentes, ed. Expiración García Sánchez, Madrid: CSIC, 2006.

49 García Sánchez, "al-Ṭignarī, Abū 'Abd Allāh”, p. 454.

50 García Sánchez, "al-Ṭignarī, Abū 'Abd Allāh”, p. 454; Ibn al-Jaṭīb, Ihātạ, ed. M. 'A. A. 'Inan, II, p. 284. Véanse de este último también I, p. 129; II, pp. 282 y 283, donde da más detalles de la vida de al-Ṭignarī y ofrece fragmentos de algunas de sus obras.

51 García Sánchez, "al-Ṭignarī, Abū 'Abd Allāh”, pp. 454-455.

52 Hijo del sultán almorávide Yūsuf b. Tāšufīn, gobernó de 1107 a 1110 y de 1115 a 1126, según afirma Ibn Luyūn en unas notas marginales. Debió de escribirla, pues, entre 1007 y 1014. Véase el prólogo del Kitāb Zuhrat al-bustān, p. 14. 456-459.
}

Ibn al- 'Awwām (S. XII-XIII), autor del enciclopédico Kitāb al-Filāḥa (Libro de Agricultura $)^{54}$, desarrolló su actividad en la zona del Aljarafe de Sevilla, seguramente en terrenos de su propiedad, en donde llevó a cabo labores de experimentación, según se puede leer en su magna obra. En ella reúne todo el saber agrícola y zootécnico, tanto andalusí como oriental, el cual resume, contrasta y recrea ${ }^{55}$. La Agricultura $\mathrm{Na}$ batea es una de las fuentes que más utiliza, junto con las de tradición greco-bizantina, mientras que entre los andalusíes los más citados son Ibn Haŷŷâŷ, Ibn Bașșāl, Abū l-Jayr y al-Ṭignarîn ${ }^{-56}$. Pero antes de incorporar en su Kitāb los comen-

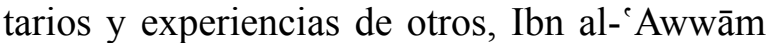
los ensaya en sus tierras; por eso llegó a decir: «Ninguna sentencia establezco en mi obra que no haya probado por la experiencia repetidas vecess ${ }^{57}$. Nos ha sido útil en este estudio sobre todo por ofrecer datos sobre economía doméstica y gestión de las explotaciones agrícolas, así como por las informaciones ofrecidas en relación con la cría y los cuidados de los caballos, ganado y animales de corral.

Además de estas seis obras fundamentales, hay una séptima de gran valor recopilatorio, el

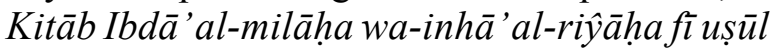
sinā'at al-filāha, que fue escrita en el periodo nazarí por el almeriense Ibn Luyūn (1282/3 $-1349 / 50)^{58}$. Este tratado geopónico está escrito en metro raŷaz, que es el más sencillo de todos, lo que hace pensar en fines mnemotécnicos de cara a su fácil aprendizaje $\mathrm{e}^{59}$. Contiene una de-

$54 \quad$ Ibn al- ${ }^{-}$Awwām, Libro de agricultura, ed. y trad. J. A. Banqueri, 2 vols., Madrid, 1802 (ed. facs. con estudio preliminar y notas por J. Esteban Hernández Bermejo y Expiración García Sánchez), Madrid: Ministerio de Agricultura, 1988. En la reproducción de los textos que hemos realizado en este trabajo se ha mantenido la grafía y acentuación de 1802 .

55 García Sánchez, "Ibn al- 'Awwām, Abū Zakarīyā’”, pp. $448-449$

56 Ibn al- Awwām, Libro de agricultura, I, pp. 8-10.

57 García Sánchez, "Ibn al-'Awwām, Abū Zakarīyā’”, pp. 449-450. La cita se encuentra en Ibn al- 'Awwām, I, p. 10.

58 Lirola Delgado y García Sánchez, "Ibn Luyūn”, pp. 41-49.

59 La actividad fundamental de Ibn Luyūn fue la docencia, por lo que las urŷuzza-s u obras redactadas en verso en metro raŷaz, término de donde procede su nombre, eran muy utilizadas por él. Como señala en el prólogo de su tratado, escribió esta obra basándose en las de autores expertos, así como en fuentes orales, recogiendo los datos que le ofrecieron personas prácticas y experimentadas. Sus fuentes principales fueron Ibn Bașșāl y, sobre todo, al-Tignarī, lo que se evidencia tanto en el texto como en las notas marginales, las cuales es posible que, incluso, fueran redactadas y copiadas por el autor almeriense. Véase, Lirola Delgado y García Sánchez, "Ibn Luyūn”, pp. 43-44. 
tallada descripción de una finca aristocrática (bustān) que aúna indicaciones arquitectónicas, paisajísticas y utilitarias, como veremos a lo largo de este trabajo; es considerada por los expertos como la única aportación personal y digna de interés de todo el tratado ${ }^{60}$.

\section{Finalidad, destinatarios y contexto históri- co de los tratados}

Aunque los libros de agricultura han sido ocasionalmente empleados como fuente para la historia económica, sobre este aspecto creemos que aún pueden proporcionar información valiosa si son contextualizados adecuadamente y se intenta determinar a quiénes estaban destinados y con qué finalidad se escribieron, cuestiones relevantes que, sin embargo, no han sido abordadas extensivamente ni existe acuerdo cerrado en relación con ellas, como veremos.

Lucie Bolens incorporó los libros de agricultura en su interpretación funcionalista de la expansión agrícola del siglo XI, según la cual estos tratados tendrían su origen en los gobernantes y sus consejeros, quienes se dieron cuenta del importante papel que tiene la agricultura en un país próspero; así pues, a modo de los dirigentes ilustrados inspirados por la fisiocracia, aquellos habrían fomentado y patrocinado a los geóponos, dando lugar a la llamada «revolución agrícola andalusí» del siglo $\mathrm{XI}^{61}$.

Por su parte, Miquel Barceló, el gran impulsor de los estudios sobre las sociedades agrícolas andalusíes a partir de la arqueología espacial, no trató el tema de manera directa, aunque en algunas de sus publicaciones dio a entender

${ }^{60}$ Lirola Delgado y García Sánchez, "Ibn Luyūn”, p. 45. Las traducciones que presentamos en este trabajo, corresponو إنهاء كتاب إبداء الملاحة ahentes al tratado agrícola de Ibn Luyūn في أصول صناعة الفلاحة الرجاحة (Kitāb Ibdā' al-milāha wa-inhā' al-riŷāha fi ușūl șinā at al-filāha o 'Libro del comienzo de la hermosura y de la culminación de la inteligencia, acerca de los fundamentos del arte de la agricultura'), parten del manuscrito fechado en 749 / 1348 en Almería, el cual está depositado en la Biblioteca de Estudios Árabes de Granada, actualmente digitalizado y accesible en línea. La descripción de la almunia se encuentra en el capítulo 157 , fols. $49 \mathrm{v}$ y $50 \mathrm{r}$. La edición y traducción de esta obra fue objeto de la tesis doctoral de Joaquina Eguaras Ibáñez, leída en 1944, aunque su publicación no se produjo hasta 1975. En esta $1^{\text {a }}$ edición, p. 28, n. 36, la autora alude a otras traducciones anteriores de este último capítulo N. ${ }^{\circ}$ 157, entre las que se encuentran la de su director de tesis, Emilio García Gómez, quien la publicó, tomándola de J. Eguaras, en "Sucursal del paraíso", p. 3, así como en Silla del Moro, p. 112, en los años 1947 y 1948, respectivamente.

${ }^{61}$ Bolens, "La révolution agricole andalouse du XIe siècle”, pp. 121-141. que consideraba esta literatura como una fuente para obtener información acerca de la organización del trabajo de los grupos gentilicios de campesinos. Paradójicamente se apoyaba en Bolens, quien afirma que en estos libros «L'impression reste d'une exploitation intensive de la propriété sous économie de main-d'œuvre et sans que soit jamais exprimé le besoin d'une réduction de travail (contrairement à Colume1le) $\rangle^{62}$, para deducir que, en efecto, «los grupos de campesinos andalusíes parecen actuar sin consideraciones de ahorro de trabajo; sus criterios debían venir, entonces, determinados por consideraciones de satisfacción comunitarias $[\ldots]\rangle^{63}$. En una publicación posterior, Barceló asumió, siguiendo a Félix Retamero, que los tratados agronómicos habrían sido favorecidos por los estados, con el fin de disciplinar los trabajos campesinos para conseguir de ciertas especies, entre las que destacan las arbóreas, los máximos rendimientos a efectos de tasación fiscal ${ }^{64}$. Sin embargo, la opinión de Retamero no parece ser exactamente esa, aunque, en efecto, asocia estos libros con el poder, considerando a sus autores «geóponos palatinos» que, trabajando en el ámbito cortesano, codificaron el saber agronómico de la misma manera que otros hicieron lo propio con los conocimientos filológicos, astronómicos o meteorológicos. Según Retamero, los tratados reflejan prácticas agrícolas llevadas a cabo principalmente en las ciudades o en sus inmediaciones, siendo la intención de estas obras, tal y como expresa Ibn Haŷȳâŷ, la de unir la práctica con un conjunto de reglas sabias y ordenadas: "La clara intención normativa de los "libros de agricultura" revela un interés por disciplinar medidas y operaciones que remite a espacios precisos, cercanos, vinculados o directamente organizados por el poder político» ${ }^{65}$. Se trataría, por consiguiente y según su consideración, de tratados destinados a servir como manuales para el cultivo de las fincas vinculadas al sultán, quien disponía de recursos para dotarlas de las infraestructuras necesarias para su riego que son descritas en estas obras, como, por ejemplo, las norias ${ }^{66}$.

${ }^{62}$ Bolens, Les méthodes culturales au Moyen Age, p. 121.

63 Barceló, Kirchner y Navarro, El agua que no duerme, p. 19.

${ }^{64}$ Barceló, "De Mulk a Mulūk: esperando a los al-murābițūn", p. 64.

${ }_{65}$ Retamero Serralvo, "La sombra alargada de Wittfogel”, p. 277.

66 Retamero Serralvo, "De Mulk a Mulūk: un conjunto de reglas sabias y ordenadas:", pp. 75-91. 
Carmen Trillo asoció la geoponía a los sultanes taifas: «floreció al calor de las cortes reales $\mathrm{y}$, en particular, debió su prosperidad a la necesidad de cuidar los jardines palaciegos y de convertirlos en pequeños paraísos lo más bellos y originales posibles $\rangle^{67}$. Si bien, más adelante se inclinaba por vincularla con el autoconsumo y con un tipo de propiedad «lo suficientemente amplia para abastecer a su dueño, pero lo bastante pequeña para ser cuidada como un jardín ${ }^{68}$. Es decir, que esta literatura habría sido gestada en el seno del poder y tendría como destinatarios al sultán y a los pequeños agricultores.

Expiración García y J. Esteban Hernández, en su estudio preliminar a la edición y traducción de Banqueri del tratado de Ibn al- 'Awwām, no tratan explícitamente el tema de la finalidad o el destinatario de estas obras, pero, de manera genérica, comentan que «son textos totalmente didácticos, dirigidos a las poblaciones campesinas, en un estilo claro, simple y preciso» ${ }^{69}$. A pesar de ello, cuando indagan sobre la figura del autor, asumen que este debió de ser un terrateniente ilustrado: «Se trata posiblemente de un noble terrateniente [...], agricultor dinámico y responsable, atento a sus propiedades [que] recomienda a los propietarios de fincas agrícolas que no dejen de visitar diariamente sus viñedos [...]; también da normas para la selección de los obreros del campo e incluso astutas recomendaciones de empresario para la organización de las cuadrillas de trabajo $»^{70}$.

Efectivamente, el examen detenido de estos tratados obliga a descartar la posibilidad de que fueran escritos con el fin de llegar a los pequeños agricultores, incluidos los campesinos que habitaban las alquerías y que han sido estudiados preferentemente por los investigadores de la escuela francesa, a partir de Pierre Guichard, y por Miquel Barceló y sus discípulos. Estos grupos unidos por lazos tribales o clánicos construyeron los pequeños sistemas hidráulicos que irrigaban unas tierras de propiedad predominantemente colectiva, de las que obtenían lo necesario para subsistir y los excedentes justos para evitar su captura por el estado. Por el contrario, la agricultura que describen los libros que venimos analizando incorpora avances y experiencias propios de cultivos intensivos y comercia-

\footnotetext{
67 Trillo San José, Agua, tierra y hombres, p. 52.

68 Trillo San José, Agua, tierra y hombres, p. 68.

${ }^{69}$ Ibn al- 'Awwām, Estudio preliminar a la edición, I, p. 18.

70 Ibn al-'Awwām, I, pp. 22-23.
}

les que nada tendrían que ver con la actividad de los pequeños campesinos o de los grupos gentilicios, como los capítulos dedicados a la contratación de trabajadores y encargados o capataces, que encontramos en Ibn Wāfid $d^{71}$, Abū 1-Jayr ${ }^{72}$, al-Tignari ${ }^{73}$ e Ibn al- ${ }^{-}$Awwām ${ }^{74}$; la construcción de mansiones de recreo, pabellones e, incluso, residencias de invitados, que vemos en Ibn Luyūn ${ }^{75}$; o la implementación de ingenios hidráulicos relativamente costosos que permitieran la extensión del riego ${ }^{76}$. Significativamente, y en relación a este último aspecto, en los tratados están del todo ausentes las grandes obras hidráulicas impulsadas por los gobernantes para el riego de sus fincas, como veremos detalladamente en el apartado 4.4, lo que interpretamos como otra prueba de que tampoco los sultanes fueron los destinatarios preferentes de estos textos.

Pero además de estas consideraciones que se derivan indirectamente del contenido de los libros de agricultura, los propios agrónomos ofrecen indicios suficientes acerca de la finalidad de sus obras y sus destinatarios. Así, en el prólogo de su tratado, Ibn al 'Awwām recoge el consejo de Qays b. ${ }^{\circledR} \bar{A} s \operatorname{sim}^{77}$ a sus hijos: «Procurad cuidar vuestra hacienda $(m \bar{a} l)$. Esto es lo que da fama célebre al noble, y lo que le produce utilidades sólidas que le satisfagan, en vez de una ociosidad indigna de alabanza ${ }^{78}$. Este hadiz ${ }^{79}$ permite deducir que los receptores no eran príncipes, pero tampoco humildes campesinos pues, obviamente, para estos la ociosidad no sería una opción. A la misma conclusión podemos llegar

71 Ibn Wāfid, Compendio de Agricultura en Ibn Haŷŷâŷ, al-Muqni' fì l-filāha, pp. 9-10 ár. /184-185 trad.

${ }_{72}$ Abū l-Jayr, Kitāb al-Filāha. pp. 139-142 / 286-288 tr.

73 Al-Ṭignarī, Kitāb Zuhrat al-bustān, pp. 103-106.

74 Ibn al- 'Awwām, Libro de agricultura, I, pp. 532-534.

75 Aunque data de fines del siglo XIII o principios del XIV, la descripción de la vivienda señorial contenida en Ibn Luyūn es una buena prueba de lo que venimos exponiendo. Véase, كتاب إبداء الملاحة وإنهاء الرجاحة في أصول صناعة الفلاحة (Kitāb Ibdā' al-milāha wa-inhā' al-rîyāḥa fì ușūl șinā at al-filāha) [Manuscrito], fols. 49v y 50r; Eguaras Ibáñez, Tratado de Agricultura (1988), pp. 171-175 y 254-255, así como también Retamero Serralvo, "La sombra alargada de Wittfogel", p. 277.

76 Así, por ejemplo, el riego se vincula normalmente a pozos y aceñas, lo que contrasta con la obtención de agua por gravedad en la mayor parte de los espacios hidráulicos campesinos que ha documentado la arqueología. Véase, Retamero Serralvo, "La sombra alargada de Wittfogel", pp. 87-88.

77 Qays b. 'Āṣim fue líder de los Banū Muqāe is y de su propia tribu y que murió en el año 47/667. Véase, Kister, “Kays b. ‘Āṣim”, $E I^{2}$, pp. 832-833.

78 Ibn al-'Awwām, Libro de agricultura, I, pp. 3-4.

79 En la religión islámica, dicho o hecho de Mahoma de transmisión tradicional. 
a partir del prólogo de Ibn Luyūn: «He recogido todo lo más aceptable y que generalmente se practica en el país de al-Andalus, a fin de que quien se interese en su estudio aprenda de una sola vez todo lo que un labrador (fallăh) puede llegar a saber al cabo de su vida $»^{80}$. De manera aún más explícita, en el prólogo o introducción a su obra ${ }^{81}$, al-Tignarī considera que el oficio (sina $\left.{ }^{\prime} a\right)$ de la agricultura necesita dos tipos de conocimientos: 'ilm bi-hāe 'ilm fì-hāa. El primero es de tipo científico teórico-práctico, es decir, el aprendizaje de todas aquellas cuestiones que competen a la agricultura; en resumen, los temas que incluyen todos los tratados agronómicos. El segundo lo constituyen los aspectos jurídicos, necesarios para llegar a la comprensión de qué es lo prohibido y qué es lo lícito, sobre todo las cuestiones referidas a las musāqāt, un tipo de contrato de aparcería para las tierras de regadío que, en palabras del autor, «tienen unos fundamentos y unas cláusulas específicas ${ }^{82}$.

Por tanto, los autores de los libros de agricultura se dirigen a un estamento de propietarios fundiarios interesados por la explotación de sus fincas de la manera más rentable, que creemos poder identificar también en otros tipos de fuentes escritas como, por ejemplo, el tratado de his$b a$ de Ibn 'Abdūn, quien señala:

El príncipe debe prescribir que se dé el mayor impulso a la agricultura, la cual debe ser alentada, así como los labradores han de ser tratados con benevolencia y protegidos en sus labores. También es preciso que el rey ordene a sus visires y a los personajes poderosos de su capital que tengan explotaciones agrícolas personales; cosa que será del mayor provecho para uno y para otros, pues así aumentarán sus fortunas; el pueblo tendrá mayores facilidades para aprovisionarse y no pasar hambre; el país será más próspero y más barato, y su defensa estará mejor organizada y dispondrá de mayores sumas ${ }^{83}$.

Precisamente estos «visires y personajes poderosos de la capital», así como otros ciudadanos propietarios de fincas, creemos que son los destinatarios preferentes de los tratados de agricultura. Se trata de unas élites terratenientes que

$80 \quad$ Ibn Luyūn, Tratado de Agricultura (1988), pp. 53 ár. / 198 tr.

81 García Sánchez, "Agricultura y legislación islámica”, pp. 179-193.

82 García Sánchez, "Agricultura y legislación islámica", p. 185. Véase este párrafo en la fuente árabe: al-Tignarī, $K i$ tāb Zuhrat al-bustān, pp. 19-20.

83 Ibn 'Abdūn, Sevilla a comienzos del siglo XII, p. 42. tenían la educación y los recursos suficientes para poder acceder a ellos - recordemos que los libros antes del Renacimiento y la invención de la imprenta eran un bien aún más raro y valioso-, y que pretendían adquirir conocimientos sobre cómo administrar y gestionar unas fincas agrícolas destinadas a obtener rendimientos más allá del autoconsumo. Otras fuentes andalusíes informan de manera indirecta sobre las clases urbanas que disponían de patrimonio fundiario; por ejemplo, la crónica de los jueces de Córdoba de al-Jušanī (finales s. X), quien describe varios acontecimientos en los que los personajes designados para la magistratura aparecen relacionados con las fincas que ellos mismos gestionan e, incluso, cultivan. Así, por ejemplo, Al-Muṣ ab b. 'Umrān al-Ḥamdān̄̄, "para aceptar el cargo del juez, puso como condición que el emir Hišam le permitiera ir a su aldea $\left(\text { day }^{\prime} a\right)^{84}$ [de Almodóvar, a $27 \mathrm{~km}$ de Córdoba] todos los sábados y domingos, circunstancia que le fue concedida» ${ }^{85}$; o también el caso de Sa ${ }^{\top} \bar{l} d \mathrm{~b}$. Sulaymān, a quien se le encontró arando con su yunta de bueyes en su aldea ( $f i$ day $a t i-h i)$, sita en el Faḥs al-Ballūt o Llano de las Bellotas (Valle de los Pedroches), por el emisario que fue a comunicarle que había sido elegido juez de Córdoba ${ }^{86}$. Este tipo de referencias tienen claramente como objetivo ensalzar a los personajes biografiados asociándolos, antes o después de desempeñar la magistratura, con una actividad que se considera especialmente digna y honorable, como es la agricultura.

El desarrollo de la Córdoba califal y, ya en el siglo XI, la expansión demográfica y el crecimiento de las capitales provinciales, incrementaron la demanda de alimentos en los mercados urbanos y, consiguientemente, el aumento de los beneficios para los productores rurales. En este contexto, los libros geopónicos tendrían como fin ilustrar a los nuevos propietarios de tierras que, sin haber sido formados en este oficio, buscaban en la agricultura una forma de negocio. Para

84 El término day'a, que ha dado lugar a nuestro arabismo 'aldea', aparece normalmente asociado en las fuentes andalusíes a propiedades particulares de un solo dueño, a diferencia de qarya (alquería) que normalmente identifica a las localidades habitadas por campesinos independientes que pueden estar unidos por relaciones gentilicias o simplemente vecinales. Véase, entre otras, Guichard, Al-Andalus frente a la conquista cristiana, p. 309.

${ }_{85}$ Al-Jušanī, Historia de los jueces de Córdoba, pp. 4647 ár. La traducción es nuestra. Cfr. p. 57 trad. Ribera.

86 Al-Jušanī, Historia de los jueces de Córdoba, pp. 108-109 ár. La traducción es nuestra. Cfr. p. 132 trad. Ribera. 
al-Ṭignarī, algunos de ellos son 'gente ignorante (qawm min al-ŷhhā̄l)' que, para explotar sus fincas y con el fin de economizar, contrataban a jóvenes y a niños a los que se pagaría menos de lo habitual, a pesar de la poca o nula experiencia que tenían. Por esa razón, el geópono granadino recomienda irónicamente que se contrate a algún jornalero:

La gente ignorante [en lo referente] a la labranza (qawm min al-ŷuhhāl bi-l-hart ) entrega sus tierras a los jóvenes y a los niños y, si uno de ellos echa a perder algo, no sabe arreglar lo dañado; tampoco distingue el tiempo en el que se siembra del que no se siembra, ni sabe cuándo se cultivan las coles y las berenjenas ni cuándo se trasplantan [del almácigo a la tierra], ni cuándo se cultivan las cebollas u otras plantas diferentes. Por tanto, [desconoce] el momento en el que se debe hacer la siembra de todo lo que se vaya [a cultivar] allí, así como tampoco sabe diferenciar lo que está en buen estado de lo que se ha echado a perder o de lo que aún permanece en pie. Y, cuando está arando con los bueyes, no distingue la izquierda de la derecha ni sabe si el arado tiene la tracción adecuada o no. Por tanto, es mejor ordenarle que esta tarea se la encomiende a su jornalero ( $a \hat{y} \hat{\imath} r)$, quien será benévolo con la yunta de bueyes y no los tratará con brusquedad si [esta labor] la comparte con él. Todo esto es una evidente desvergüenza y una falta de corrección con respecto a los trabajos de los agricultores (a'māl al-fallāhīna $)^{87}$.

En definitiva, consideramos que no existe en los tratados evidencia alguna que permita pensar que se trate de manuales que pretendieran servir de guía para futuros jardineros reales, ni encontramos en ellos una «intención claramente normativa», como opina Retamero. Es cierto que los textos recogen anécdotas con relación a los sultanes desde tiempos de 'Abd al-Raḥmān I, teniendo en cuenta, como es lógico, que algunos de los geóponos trabajaron para los monarcas cuidando de sus fincas. Por ejemplo, Abū 1-Jayr dice de la finca sevillana de al-Mu'tamid (gob. 1069-1090): «Yo mismo he observado muchos árboles de las especies antes aludidas en la huerta $(h \bar{a}$ ' $i t)$ del rey de nuestra comarca. Se afirma que los plantó el abuelo [Abū 1-Qāsim Muhammad b. Ismāêll b. 'Abbād (gob. 1023-1042)] del monarca, y que se han encargado de ellos tres mandatarios ( $r$ ' $^{\prime} a \bar{a}^{\prime}$ ), todos los cuales han muerto una vez cumplidos los sesenta años ${ }^{88}$. Esto no significa que los tratados de agricultura

\footnotetext{
87 Al-Ṭignarī, Kitāb Zuhrat al-bustān, p. 114.

88 Abū l-Jayr, Kitāb al-Filāha, pp. 229 trad. / 60 ár.
}

se escribieran para los soberanos, aunque sí parece lógico suponer que también ellos, como terratenientes, se encontraban dentro del grupo de potenciales destinatarios, compartiendo el objetivo de hacer más productivas sus propias fincas $\mathrm{y}$, de esa manera, aumentar sus riquezas, pues conviene recordar que en los Estados islámicos medievales existía una clara distinción entre la Hacienda Pública o Tesoro Público (Bayt al-māl o Jizānat al-māal) y el Patrimonio Real o tesoro privado del soberano (mustajlaș o jāsșiyat bayt $a l-m \bar{a} l)^{89}$. A este último pertenecerían, por ejemplo, algunas de las más productivas fincas que circundaban Granada en época nazarí, según describe Ibn al-Jațīb:

La llanura de la ciudad (sahl al-madina) está rodeada por detrás de la muralla de almunias (munà) y de huertas ( $\hat{y} a n n \bar{a} t)$. Son bienes inmuebles de alto valor ('aqār tamin), [que les aportan] importantes ganancias ( $a z \bar{i} n$ fá'ida), ininterrumpidas cosechas (muta'āqaba galla), y no se sabe que [en algún momento] [estas tierras] hayan estado muertas (lā ya 'rifu al-ŷimām). No se ha dejado de sembrar (lā yufāriqu al-zar') en la tierra blanca (ard bayd $\left.\bar{a}^{\prime}\right)$ [o tierra de labor], cuyo precio del marjal (taman al-marŷa') es muy elevado, alcanzando los veinticinco dinares de oro. Se sabe que, entre [esas tierras], se encuentran [algunas] propiedades pertenecientes al sultán [mustajlaș al-sulțān], que se tiene dificultad para decir el valor que tienen (o que pueden alcanzar) (mā yad̄iqu'an-hu nițāqu al-qīmati) por la longitud (dar $\left.{ }^{\circ a n}\right)$ [que poseen], el lugar envidiable ( gibtat $\left.^{a n}\right)$ [donde están situadas] y la disposición (intizāamm ${ }^{a n}$ ) [de la que gozan]. Se les atribuyen casas que salen como estrellas ( $d \bar{u} r$ nāŷima), torres elevadas (burūŷy sāmiya), amplias eras (bayādir famīha) y excelentes (mātila) palomares (qașāb li-l-hamāyn / hamā'im) y gallineros (dawā̂ŷyin).

En realidad, el estamento social andalusí que podía estar interesado en los libros de agricultura sería el mismo al que siempre ha estado orientado este tipo de literatura a lo largo de los siglos. Así, por ejemplo, Columela deja clara la condición de aquellos a quienes está dedicada su obra: se trata de acomodados propietarios de tierras que residen en la ciudad, como él mismo o su vecino Silvino: «la hacienda más cómoda es la que está cerca de la ciudad, a la cual, aun el hombre que tiene ocupaciones pueda dar con facilidad una vuelta todos los días después de haber concluido los negocios del foro» ${ }^{90}$. Durante el Renacimien-

\footnotetext{
89 Molina López, "Más sobre el mustajlaṣ", p. 112

90 Columela, Los doce libros de agricultura, p. 13.
} 
to también proliferaron en Europa los tratados de agricultura - entre ellos el de Gabriel Alonso de Herrera publicado en 1513-, elaborados por autores que pertenecían a la élite intelectual y, en la mayor parte de los casos, a un estrato social alto, por lo que se ha concluido que sus enseñanzas, obtenidas de su propia experiencia personal y cotejadas con las expuestas en las obras clásicas de la Antigüedad y del Medievo, se dirigen ante todo a sus pares estamentales, es decir, a los dueños de tierras cercanas, a quienes muestran la manera de mejorar su rendimiento, de instruir a sus campesinos, de aclimatar nuevas especies y de obtener provecho de la venta de excedentes. Los labradores, por lo tanto, accederían a los contenidos de los volúmenes por medio de las órdenes que recibían de sus patrones ${ }^{91}$.

La misma opinión defiende Eloy Terrón, quien considera que ni los tratados geopónicos antiguos ni los modernos fueron escritos para los pequeños y medianos agricultores, puesto que, además de su analfabetismo generalizado, «no necesitaban que nadie viniera a darles instrucciones teóricas de cómo tenían que realizar las faenas de su oficio» ${ }^{92}$.

Las fincas que cultivaban el estamento de agricultores y terratenientes a que nos referimos serían de carácter plenamente agropecuario, tanto de secano como de regadío, aunque entre ellas también se encontraría el tipo de propiedad que de manera genérica venimos denominando 'almunia', en el que se combinaba el solaz y recreo con la explotación agrícola. Además de constituir una fuente de ingresos, estas fincas se distinguían por acoger edificios residenciales a los que se podían retirar temporalmente sus propietarios, según confirman, por ejemplo, el poeta Hiāzim al-Qarțāŷannī en su Qasīda Maqșūra (s. XIII) ${ }^{93}$, el polígrafo granadino Ibn al-Jațīb en al-Ihâța (s. XIV) ${ }^{94}$ o los viajeros y humanistas Jerónimo Münzer (s. XV) y Luis de Mármol (s. $\mathrm{XVI})^{95}$. Su presencia en al-Andalus se remonta a los años inmediatos a la conquista musulmana,

\footnotetext{
91 Beutler, "Un chapitre de la sensibilité collective", p. 1291, en Quirós, "El Libro de Agricultura", p. 9.

${ }_{92}$ Terrón, "La experiencia derivada de la práctica agropecuaria", pp. 26-27, en Quirós, "El Libro de Agricultura", p. 10.

93 Pocklington, La Casida Macsura de Házim al-Cartayánni, p. 13.

94 Ibn al-Jațīb, Al-Ihâța, ed. B. Derradji, I, p. 215; ed. 'Inān, I, p. 117.

95 Münzer, Viaje por España y Portugal. Reino de Granada, p. 119; Simonet, Descripción del reino de Granada, p. 196.
}

de acuerdo con las referencias contenidas en la crónica anónima Ajbār Maŷmu 'a $a^{96}$, confirmadas por la construcción de la almunia al-Rușāfa por 'Abd al-Raḥmān el Emigrado en memoria de su homónima siria. No obstante, sería a partir del siglo XI cuando proliferaron significativamente por toda la península, impulsadas por algunos reyes taifas que fundaron almunias con jardines y huertos en torno a sus capitales; por ejemplo, la «Huerta del Rey» (Ŷannat al-Sultān) de al-Ma'mūn de Toledo, que fue, al parecer, proyectada por los agrónomos Ibn Wāfid e Ibn Bașsāal, como vimos anteriormente. También en ese momento al-Mu tașim [1051-1091] mandó construir «en las afueras de la ciudad de Almería, una huerta (bustān) de artística traza con palacios de peregrina factura. A ella llevó, entre otras cosas, los más singulares frutales como el platanero en sus diversas especies, y la caña de azúcar [...]. Es conocida por al-Șumādihiyyya y se encuentra muy cerca de la ciudad, rodeada por otras muchas huertas (basātīn) parecidas $\rangle^{97}$.

De igual manera, en Valencia los inmigrantes cordobeses que se establecieron en la ciudad a comienzos del siglo XI «construyeron mansiones (manāzil) y palacios (qușūr) y establecieron prósperas (zāhira) huertas/almunias (basātīn) y espléndidos (nâdira) jardines (ryaḍāt), por donde hicieron correr el agua en abundancia», según señaló Ibn Hayyān y recogió posteriormente Ibn Bassām ${ }^{98}$. Esta última referencia nos recuerda que este tipo de propiedades fundiarias no solo estaban vinculadas a personajes próximos al poder, sino que constituían una fuente de ingresos para las clases altas en general. Así también, en el Pla de Lérida predominaban los espacios destinados al pasto para el ganado, que eran aprovechados por las almunias, algunas de las cuales se dedicaban exclusivamente a esta actividad económica. Según Jesús Brufal, estas almunias leridanas proliferaron a partir del siglo XI, en una coyuntura social y económica en que la necesidad de aumentar la productividad del campo favoreció la adquisición de bienes rurales por parte de la oligarquía capitalina:

96 Esta crónica del s. XI habla del Qanāt 'Ámir, una propiedad perteneciente a uno de los primeros jefes yemeníes que se instalaron en la Península, cuyo nombre era 'Āmir. La fuente la identifica con el nombre de munya. Véase, Ajbar Machmuâ, trad. y anot. E. Lafuente Alcántara, Madrid, 1867, pp. 63 ár. / 67-68 trad. Asimismo, García Sánchez, E., "Las huertas del Generalife en época islámica”, p. 58.

97 Al- 'Udrīi, Nuṣūṣ, p. 85.

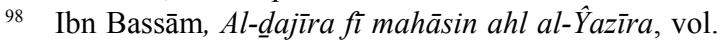
3, p. 17. 
[...] son explotaciones agropecuarias que tienen un propietario urbano. Representan el carácter hegemónico de la ciudad sobre el territorio a través de sus élites urbanas que residen en ella, conocidas también como la «gente de la ciudad ${ }^{99}$.

En resumen, en el siglo XI, las fuentes escritas árabes y cristianas, así como la arqueología, permiten detectar un incremento notable de las explotaciones agropecuarias en manos de las élites y los estamentos acomodados de las ciudades de al-Andalus, tanto de almunias como de fincas estrictamente orientadas a la producción, coincidiendo precisamente con el auge de la literatura geopónica.

En el epílogo de su obra, Ibn Ḥaŷȳâŷ especifica a quiénes estaba destinada y a quiénes no, opinión compartida por Ibn al- 'Awwām, pues recoge la cita en su prólogo:

Querido hermano, con el fin de obsequiarte, he completado y ultimado mi libro en torno a la agricultura, conforme al objetivo propuesto. De esta forma, te evito recurrir a las opiniones de gentes ignorantes y rústicas que carecen de base científica y claro fundamento, a pesar de su vasta práctica y vinculación con este oficio ${ }^{100}$.

Es decir, Ibn Haŷŷâŷ identifica a unos campesinos dotados de conocimiento práctico, pero no científico, que indudablemente no son aquellos a los que estaba dirigido su libro; un antagonismo entre campesinos y hacendados urbanos al que también hace referencia Ibn 'Abdūn:

El cadí debe ordenar a los habitantes de los pueblos que cada pueblo tenga un guarda jurado para impedir que las propiedades particulares sean tratadas como las comunes, porque los campesinos suelen mirar como propias las fincas de las gentes de la ciudad ${ }^{101}$.

Los geóponos no desconocían el valor que tenía la experiencia acumulada durante generaciones por los pequeños agricultores de las alquerías, por lo que su desdén no estaría asociado a la soberbia de los tratadistas o a la relación de vecindad entre unos y otros, como afirma Retamero $^{102}$. Más bien la rivalidad tendría su origen, según creemos, en el tipo de agricultura destinada fundamentalmente al autoconsumo que

99 Brufal, "La Lleida de secano", p. 261.

100 Ibn Haŷŷầy, al-Muqni' fì l- filāha, pp. 122 ár. / 327 trad. Fue recogido posteriormente por Ibn al- 'Awwām. Véase, Libro de agricultura, I, p. 2.

101 Ibn 'Abdūn, Sevilla a comienzos del siglo XII, p. 152.

102 Retamero, "De Mulk a Mulūk", p. 87. aquellos practicaban, en fuerte contraste con la orientación intensiva y comercial en la que estaban interesados los autores de los libros y sus destinatarios. Estamos ante un tipo de desajustes relacionados con cambios en el modelo social durante este periodo, concretamente con la estructura de la propiedad de la tierra, pues la expansión de los terratenientes urbanos no solo se realizó mediante la colonización de nuevos espacios agrarios, sino también a costa de la apropiación de fértiles tierras pertenecientes a pequeños campesinos. Esta competencia ocasionó conflictos de los que existen indicios en las fuentes escritas; por ejemplo, Ibn Hayyān, contemporáneo de los hechos que describe, explica que, en tiempos de los dos copríncipes eslavos de Valencia, Mubārak y Muzaffar, «recaudaban los impuestos con el mayor rigor de todas las categorías de la población, hasta el punto de que la situación de sus súbditos se degradó ${ }^{103}$. Frente a la presión fiscal del Estado, los hombres de religión tendrían la obligación de limitar o desautorizar los impuestos ilegales de acuerdo con el islam, defendiendo así a los propietarios legítimos de la tierra, como reconocen unos ulemas que, en cierta ocasión, según al-Ṭurțūšīi, acusaban a los visires:

Vosotros sois los que os coméis las haciendas de las gentes, sin provecho para ellos, y consideráis lícito el oprimirlos sin razón; los que priváis, poco a poco, de sus medios de vida, arrebatándoselos como precio de vuestro soborno y de vuestra prevaricación; los que queréis la tierra sin derecho ${ }^{104}$.

Por causa de la presión impositiva, según Ibn Hayyān,

las gentes emigraron unas tras otras de las regiones que ocupaban, las cuales, a fin de cuentas, se arruinaron. Mientras tanto, a ellos y a sus pares todo les sonreía, gracias al impuesto [jarâŷy que les procuraba rentas abundantes $[. .$.$] , la gente no$ pudo hacerle frente sino emigrando de sus casas y abandonando sus alquerías [qurà]. Aquellos dos bárbaros y sus secuaces no se conmovían por ello, y no dudaban en someter a las mismas condiciones a los que se establecían allí después de ellos.

Es decir, la imposibilidad de hacer frente a las cargas impositivas y las deudas daba lugar a la emigración de los campesinos y la expropiación de las fincas, que pasaban a manos de

\footnotetext{
103 Guichard, "Crecimiento urbano y sociedad rural", pp. 164 ss.

104 Al-Ṭurțūšs̄i, Lámpara de los príncipes, tomo I, p. 111.
} 
la aristocracia terrateniente: «[...] se apropiaban los pueblos cuya gente había emigrado para hacer de ellos explotaciones particulares [ diy $^{\prime} \bar{a}{ }^{\prime}$ mustajlaṣa]». De hecho, la existencia de estas aldeas pertenecientes a individuos ricos que las habían adquirido durante «los días de los rebeldes», está igualmente atestiguada en varias fetuas de Ibn al-Hāâŷy ${ }^{105}$. Finalmente, algunos de esos campesinos libres que fueron desposeídos de sus tierras, después volvieron a trabajarlas, pero como jornaleros empleados por los nuevos amos:

Y cuando uno de estos notables daba su nombre a una de esas explotaciones, sus antiguos habitantes volvían allí, aceptándolo como amo, trabajando a cambio de una parte del producto y con la esperanza de que él les protegería contra los reveses de la fortuna.

De acuerdo con Ibn Hayyān, este proceso no solo aconteció en la región de Valencia, sino que «eso fue lo que hicieron la mayor parte de los rebeldes que se adueñaron de las regiones del Andalus o se sublevaron en sus confines, tras la disgregación del poder de la Comunidad [sultān al-ŷama ' $a$ ] en Córdoba al final de la dinastía de los Banū 'Āmir» ${ }^{106}$.

La situación crítica del campesinado andalusí por causa de la presión impositiva la documenta también el alfaquí pro almorávide al-Ṭurțūšš:

[...] preponderaron los musulmanes sobre el enemigo, y el poder de este se vio abatido y quebrantado, mientras las tierras estuvieron repartidas en poder de las tropas, las cuales les hacían producir y trataban benignamente a los campesinos [...]. Así continuaron las cosas hasta los últimos tiempos de Benabiamir, el cual sustituyó el pago de las tropas por una soldada mensual que se percibía en dinero e impuso un tributo sobre las tierras, de cuya cobranza se encargaron las mismas tropas. Estas esquilmaron al pueblo, devastaron sus haciendas y lo dejaron arruinado. Ahuyentáronse las gentes y no fue posible a las tropas seguir explotando los campos $[\ldots]^{107}$.

Según Ahmed Tahiri «al encabezar la cúspide del poder a escala local o provincial, la nueva casta acabó sometiendo a los productores a una serie de obligaciones tributarias», de ma-

\footnotetext{
105 Benaboud, "La economía de al-Andalus", p. 238.

106 Guichard, "Crecimiento urbano y sociedad rural", p. 160.

107 Al-Ṭurțūšs̄i, Lámpara de los príncipes, tomo II, pp.
}

nera que se vieron obligados a trabajar la tierra sujetos a prestaciones de todo tipo, lo que alteró seriamente las características sociales de los sectores productivos de la 'amma rural ${ }^{108}$. La presión fiscal sobre los campesinos, unida al aumento de la demanda de bienes de consumo en los mercados ciudadanos, ocasionó que muchos de esos agricultores arruinados o desposeídos engrosaran al proletariado urbano, uno de los factores que explica el crecimiento de las medinas en el siglo $\mathrm{XI}^{109}$. Ibn al-Jaṭib recoge una significativa historia acerca de los peligros que acechaban a los campesinos cuando se les agobiaba con impuestos en exceso. En concreto trata de un súbdito de Ibn Mardanīš que tenía en los alrededores de Játiva, «una pequeña finca de la que vivía, pero los impuestos superaron sus ganancias y huyó a Murcia, aunque Ibn Mardan̄̄š tenía establecido que, quien huyese ante el enemigo, se le confiscarían los bienes para el tesoro. El hombre de Xátiva contaba: cuando llegué a Murcia, huido de mi patria, me coloqué en la construcción y llegué a reunir dos mithqales de oro [...]», a lo que siguen diferentes peripecias cuyo hilo conductor es la exagerada carga impositiva que ejerció sobre sus súbditos el Estado mardanisíi ${ }^{110}$. Es decir, el antiguo campesino perdió su tierra por causa de los impuestos y acabó emigrando a la ciudad para convertirse en obrero de escasa cualificación, decisión forzada que solo se tomaba cuando no quedaba otra salida. En los casos más extremos, la presión fiscal podía dar lugar a que los más desfavorecidos acabaran cayendo en la pobreza, tal y como ha podido determinar Ana M. ${ }^{\mathrm{a}}$ Carballeira: «The situation of social inferiority left the poor particularly vulnerable and thus susceptible to injustices like the expropriation of their property by those in positions of power» ${ }^{111}$.

Por consiguiente, el contexto histórico en el que se debe situar la proliferación de la literatura geopónica andalusí en el siglo XI es el de la expansión demográfica y económica, uno de cuyos pilares fue precisamente la eclosión de la agricultura comercial y, con ella, la de un tipo de explotaciones vinculadas a propietarios urbanos

108 Tahiri, Las clases populares, p. 62.

109 Por ejemplo, Azuar, "Formación de la ciudad"; Bosch, "El siglo XI en al-Andalus", p. 190; Guichard, "Crecimiento urbano y sociedad rural", p. 164 y ss; Guichard y Soravia, Los reinos de taifas, pp. 186-191 y 200; Jiménez Castillo, "La ciudad y el reino de Murcia", pp. 177-190; Mazzoli-Guintard, Villes d'al-Andalus, p. 187.

110 De Epalza y Rubiera, "La sofra (sujra)", p. 34.

111 Carballeira Debasa, "Living on the margins of society”, pp. 145, 148, 149 y 154. 
más o menos acomodados ${ }^{112}$. Esta «revolución» agrícola, presentaría las características de los procesos de comercialización descritos por la antropología comparada, en que las élites no se conforman con las exacciones tributarias, sino que aspiran a incrementar sus ingresos mediante la apropiación de la tierra y la práctica directa de una agricultura orientada a la comercialización ${ }^{113}$. De esta manera, los libros de agricultura andalusíes serían en sí mismos un exponente del desarrollo tecnológico, uno de los aspectos que, junto con el demográfico, se encuentra en la base de toda expansión económica preindustrial. De lo expuesto se concluye que estos tratados no solo tienen valor desde el punto de vista botánico, sino que pueden servir como fuente de información muy valiosa acerca de unas cuestiones históricas sobre las que, por otra parte, disponemos de muy pocos datos, como la propiedad rústica de la aristocracia andalusí y los modos en que se explotaba y se organizaba el trabajo en ella, según trataremos demostrar a continuación.

\section{El espacio y el trabajo agrícola según los libros de agricultura}

Los libros de agricultura tratan casi todos los aspectos de las ciencias agrícolas; no obstante, ahora dejaremos de lado los aspectos puramente botánicos y técnicos para centrarnos en aquellos más propios de la historia económica. No pretendemos ser exhaustivos en este análisis, sino tratar sencillamente de demostrar que, una vez ubicados estos libros en su contexto histórico, pueden convertirse en una fuente de información muy valiosa en relación con la organización y el funcionamiento de las propiedades fundiarias de las elites andalusíes, al menos para el periodo en el que fueron escritos.

\subsection{Organización espacial}

El autor almeriense Ibn Luyūn, en su capítulo titulado: «Sobre lo que se ha de elegir en la disposición de las huertas (basātīn), sus vivien-

112 Jiménez Castillo y Simón García, "El poblamiento andalusí en las tierras de secano", pp. 215-259; Jiménez Castillo, "Fincas aristocráticas en la Murcia islámica", pp. 749-791, Jiménez Castillo, "Reales y rahales de la Murcia andalusí", pp. 389-436; Jiménez Castillo, "La expansión agrícola", en prensa; Malpica Cuello, "Formación y desarrollo del sistema irrigado en al-Andalus", p. 55.

113 Kautsky, The Politics of Aristocratic Empires, p. 291; Lenski, Poder y privilegio, pp. 201-308. das (masākin) y las casas de labor (diyār al-bādiya)», describe cada uno de los elementos que deben formar parte de una almunia ideal, a la que se refiere como bustān (pl. basātīn), explicando cómo han de disponerse los edificios residenciales, así como las diferentes áreas cultivadas e infraestructuras hidráulicas, distinguiendo las que tienen un carácter más recreativo de las que son de naturaleza esencialmente productiva. Explica que las flores y plantas ornamentales se han de situar cerca de la residencia y las especies utilitarias en áreas periféricas e, incluso, indica el tipo de plantas que han de flanquear los paseos:

Para la elección [del emplazamiento de] las viviendas de las fincas (basātīn) [se debe considerar un lugar] en alto (išra $f$ ), que [facilite] su protección (hifż) y vigilancia (ta 'yiyn). [Las viviendas] deben mirar hacia el sur (qibla) y [han de disponerse] cerca de la puerta [de entrada a la finca]. La alberca/el zafariche (șahrîy) y el pozo $(b i$ 'r) [deben situarse] en lo más alto o, en lugar del pozo, una acequia (sāqiya), cuyas aguas corran por la umbría [...]. Cerca de esta alberca, se deben plantar especies que no pierdan sus hojas y que sean alegres a la vista. A una cierta distancia de estas, se disponen las flores (anwār) y, tras ellas, los árboles de hoja perenne (wāqy al-ašŷar $r$ ). En cuanto a las viñas (dawāl $\bar{\imath})$, se deben plantar en los laterales de la vivienda $y$, en medio de todo, que abunden los emparrados ('arā' $i s ̌ s)$. Y, en la parte inferior de estos emparrados, que los paseos (mamāš $\bar{l})$ rodeen el jardín (bustān), cercándolo [...]. La base de todo lo que crezca en un jardín (yubassatinu) es la proximidad [a la vivienda], ya que estará más cuidado (așwan) por esta razón ${ }^{114}$.

Por su parte, al-Ṭignarī indica dónde instalar las aceñas y los zafariches en la finca con el fin de que sean más efectivos, pero también con el propósito de que el dueño y sus allegados puedan gozar del relax que ofrece pasear junto a estanques y canales sin tener que atravesar los huertos. Estos espacios cultivados y resguardados pueden, sin embargo, ser contemplados desde esta parte alta de la propiedad. Sobre la seguridad de estos huertos, al-Tignarī lo deja claro: si es preciso, que se protejan más que las casas. Y, por último, nos queda señalar una cuestión de terminología, a saber, la 'polisinonimia' presente en este pequeño párrafo del geópono granadino, que demuestra que los términos bustān,

114 Ibn Luyūn, كتاب إبداء الملاحة و إنهاء الرجاحة في أصول (Kitāb Ibdā' al-milāha wa-inhā' al-riŷāha fì uṣūl șinā'at al-filāha), fol. 49v. 
yanna y yinān se pueden usar indistintamente para denominar una misma zona cultivada:

\begin{abstract}
Al-Filāha al-Rūmiyya ${ }^{115}$ : al trazar la aceña (sawānī) y el zafariche (șahārîy) procura que estén cerca de las puertas de las huertas ( $\hat{y} a n n \bar{a} t$ ), en un lugar elevado, en la zona más alta de todos los huertos ( $\hat{y}$ inānn), con el fin de que, quien desee contemplar (farŷa) el huerto (bustān), no tenga que atravesarlo. [Esto sucede] cuando [la persona] tiene la intención de entrar en el huerto (bustān), [y pasear] por los lugares por donde corre el agua y están los zafariches (șahārîy), por el sosiego (rāha) que esto [ofrece]. Cuando todo ello se encuentra cerca de la puerta, no lo tiene que atravesar más que quien tenga la necesidad de hacerlo. El huerto (ŷinān) debe estar preservado del paso de la gente, pero dispuesto para su contemplación. $Y$, si es necesario, que se protejan los huertos (basātīn) de una manera más fuerte que las viviendas $(d \bar{u} r)^{116}$.
\end{abstract}

Más allá de estos huertos ajardinados o espacios de regadío junto a las viviendas, en los que se situaban cultivos que unían su valor práctico al ornamental, Ibn Luyūn ubica las tierras de labor destinadas plenamente a cultivos de consumo «a cierta distancia de todo lo anterior» reservando una parte de la finca «a la tierra de labor (ard bayd $\left.\bar{a}^{\prime}\right)^{117}$, para que se siembre lo que uno quiera que brote» ${ }^{118}$.

Todos los elementos que según los libros de agricultura forman parte de estas fincas son los

115 El texto de Casiano se tradujo directamente del griego al árabe en el s. VIII con el título de al-Filāha al-Rūmiyya y constituye una de las fuentes de donde toma información al-Ṭignarī. Véase, para ello, García Sánchez, "Las fuentes citadas en el tratado agrícola de al-Ṭignarı”, p. 209. Como señala Carabaza Bravo, al-Filāha al-Rūmiyya solo propone lugares elevados y no próximos a establos y graneros. Véase, "El agua en los tratados agronómicos andalusíes", p. 28.

116 Al-Ṭignarī, Kitāb Zuhrat al-bustān, pp. 94-95.

117 Los términos ard bayḍā' o 'tierra blanca' hacen referencia normalmente a la tierra inculta y baldía, tanto en los tratados agrícolas como en los jurídicos. Sin embargo, en los histórico-geográficos se alterna este significado con el contrario, es decir, con tierras fértiles. El geópono Ibn Luyūn es la excepción, pues se refiere con estos términos a la tierra de labor, tal y como también lo vemos en su coetáneo Ibn alJațīb cuando habla de la tierra de la vega de Granada bañada por el Genil, cuando dice: «No se ha dejado de sembrar ( $l \bar{a}$ yufāriqu al-zar') en la tierra blanca (ard bayḍa '), cuyo precio del marjal (taman al-marŷa') es muy elevado, alcanzando los veinticinco dinares de oro». Véase, Al-Ihạța, ed. B. Derradji, I, p. 231; ed. 'Inān, I, p. 125. Asimismo, consúltese, Jiménez Castillo, "Reales y rahales de la Murcia andalusí', p. 411.

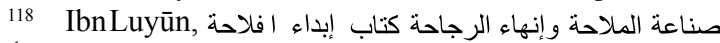
في أصول (Kitāb Ibdā' al-milāhà wa-inhā' al-rîyāha fì uṣūl șinā at al-filāha), fol. 49v. mismos que conocemos a través de otras fuentes, como, por ejemplo, los modelos ideales contenidos en los formularios notariales, lo que no deja lugar a dudas acerca del tipo de propiedad del que estamos tratando. Así, según Ibn al-`Aț̣ār:

Si el objeto de toma de posesión fueran fincas (amläk) [...] has de decir: de todas las fincas descritas y cuyos límites han sido especificados en este escrito, sitas en tal alquería (qarya) de tal región de la circunscripción de Córdoba (o de tal provincia). La descripción de estos [bienes incluye] una casa $(d \bar{a} r)$ con tales límites, un muladar (dimna) de tierra con tales límites, un fundo (haql) con tantos límites, un viñedo (hadiqa a'nāb) con tales límites, una almazara de aceite ( ma $^{\prime}$ zara li-lzayt) con tales límites, tantos y tantos pies de olivo (așlan min šaŷar al-zaytūn) en tal lugar de la alquería (qarya) conocida por tal ${ }^{119}$

Era importante que esta propiedad estuviera cercada; al respecto, Ibn Luyūn afirma: «Resulta excelente proteger la finca (bustān) con una tapia ( $\left.h \bar{a}{ }^{\prime} i t\right)$ que la rodee totalmente» ${ }^{120}$; incluso que se empleen algunas especies de árboles que contribuirían a su protección y aislamiento:

En los límites [de la finca, se plantan] árboles como la higuera $(t \bar{i} n) \mathrm{u}$ otros semejantes que no causen ningún perjuicio. Todos los grandes frutales deben plantarse en la parte norte, con el fin de que protejan del viento del norte todo lo que allí haya plantado o instalado (aqwām), y sin que lleguen a tapar el sol cuando empieza a calentar ${ }^{121}$.

Por el geópono Abū 1-Jayr sabemos que no solo se cerraban con muros los huertos y los viñedos, sino también las grandes fincas ( $f a d \bar{a}-$ dìn). Él dirá: «Te diriges a un campo (faddān) que hayas vallado totalmente con un seto (bi-si$y \bar{a} \hat{y})$ o muro (aw hă 'it $)[\ldots]\rangle^{122}$.

Aparte de las obras geopónicas, los tratados jurídicos también hablan de los cercados, realizados con vallas, muros o setos, los cuales tenían varias funciones: como delimitadores de la propiedad, como medio de adquisición de las

\footnotetext{
119 Ibn al-'Ațtāar, Kitāb al-watā 'iq wa-l-siŷillāt, pp. 520 ár. / 781 trad.

120 Ibn Luyūn, في أصول وإنهاء الرجاحة كتاب إبداء الملاحة (Kitāb Ibdāa 'al-milāha wa-inhāa 'al-riŷāha fì uṣū șinā'at al-filāha), fol. 49v. Para consultar los cerramientos ( hẩ it / hadìqa / galqa) en al-Andalus, tanto en el huerto como en el jardín ( $\hat{y} a n n a /$ bustān), véase García Sánchez, "Cultivos y espacios irrigados en al-Andalus", pp. 28-29.

121 J. Eguaras no traduce esta última frase.

122 Abū 1-Jayr, Kitāb al-Filāha, pp. 145 ár. / 291 tr.; García Sánchez, “Cultivos y espacios agrícolas”, p. 29.
} 
tierras jurídicamente muertas $(m a w \bar{a} t)^{123}$, como protectores de los cultivos que había tras ellos o para evitar los destrozos que pudiera ocasionar el ganado ${ }^{124}$. Resguardados también estaban los reales (riyāọ), propiedades de carácter aristocrático situados en la periferia irrigada de las ciudades y poblados importantes del Šarq al-Andalus, los cuales, según Guichard, comprendían una casa de recreo rodeada por un jardín ${ }^{125}$. La documentación confirma que estaban vallados mediante tapias de tierra y/o setos y que protegían los animales que allí se criaban, así como árboles frutales, hortalizas y aperos ${ }^{126}$. Otras fuentes textuales que prueban la existencia de cercas son las histórico-geográficas, como es el caso de al-Jušanī y su Historia de los jueces de Córdoba, en donde habla del cercado (hayt) de una almunia (munya) propiedad del juez al-Habīb, la cual estaba realizada con dos filas de árboles ${ }^{127}$ Por otra parte, hemos de recordar que, para la construcción de la huerta de al-Buhayra en 1171, se compraron las tierras que rodeaban a los palacios para plantar olivos, viñas y frutales $y$, posteriormente, todo el conjunto se rodeó con un muro hecho de cal, arena y piedras, transportadas estas últimas, al igual que ladrillos, cal y frutales, por las bestias y esclavos del 'Amīr al-Mu'minīn ${ }^{128}$.

\subsection{La casa}

Ibn al 'Awwām recomienda, citando un proverbio (matal), «que el labrador (șạhib al-day'a,

123 La mayoría de los juristas andalusíes consideraba que esta labor vivificadora debía ir acompañada de la intención de cultivar en un periodo corto de tiempo, ya que, el cerramiento por sí solo no era considerado normalmente un acto vivificador por el que cualquier individuo pudiera adquirir una tierra muerta. Véase, Camarero Castellano, "Las labores vivificadoras como medio de adquisición de la tierra muerta", pp. 14-16.

124 Al-Qayrawān̄̄, al-Risāla, pp. 214 ár. $/ 215$ tr. y pp. 270 ár. / 271 tr.; Ibn Habīb, Kitāb al-Wāạihha, pp. 122-123 ár. / 124 tr.; al-Wanšarīsī, al-Mì yār, VIII, pp. 335-338 y 351-353; Linant de Bellefonds, $E I^{2}$, III. s. v. ihy $\bar{a}^{\prime}$, p. 1080. Camarero Castellano, Sobre el 'estado de yā' iha'. Teoría y práctica jurídica de la calamidad rural y urbana en Al-Andalus, pp. 47-49 y 122.

125 Guichard, Les musulman de Valence et la Reconquête, II, pp. 374-379; Guichard, Al-Andalus frente a la conquista cristiana, pp. 504-511.

126 Jiménez Castillo, "Fincas aristocráticas en la Murcia islámica", pp. 772-773; Jiménez Castillo, "Reales y rahales de la Murcia andalusí", p. 413.

127 Al-Jušanī, Historia de los jueces de Córdoba, pp. 188 ár. / 234 trad. Ribera.

128 Ibn Șaḥīb al-Salāt, al-Mann bi-l-imāma, pp. 189190. lit. dueño de la finca rústica) por sí mismo debe visitar freqüentemente su heredad (day'a), y no ausentarse de ella, principalmente en el tiempo de las labores, como la cava \&c. para que le conste del cuidado y vigilancia de los jornaleros» ${ }^{129}$. El contenido de esta sentencia confirma de nuevo el tipo de terrateniente urbano al que estaban destinados estos libros, y conviene con la existencia generalizada de viviendas en las fincas particulares que debieron de funcionar como segundas residencias, aspecto que conocemos bien gracias a las fuentes escritas y, sobre todo, a la arqueología, aunque la mayor parte de las conservadas o excavadas forman parte de almunias pertenecientes a diferentes soberanos ${ }^{130}$.

Ibn Luyūn indica cómo deben disponerse cada uno de los componentes del espacio doméstico, así como su entorno inmediato, y cuáles son sus características principales. En primer lugar, explica cómo debe ser el emplazamiento y la orientación de la casa ${ }^{131}$.

Un lugar en alto (ǐsrāaf) que facilite su protección y vigilancia. Debe mirar hacia el sur y [ha de disponerse] cerca de la puerta [de entrada a la finca]

En cuanto a los accesos de la vivienda ${ }^{132}$ :

Debe tener dos puertas, para que esté más protegida y sea mayor la tranquilidad del que la habita. [...] La puerta principal tendrá bancos (mașātị) y a su alrededor (hawla-hu) un zaguán (rahaba) proporcional [al edificio]

No es de extrañar que el autor incida en la presencia de los bancos del zaguán, pues este tipo de elementos permitían descansar a los que esperaban a ser recibidos en el interior de la casa, pero también servían para que el dueño contara con un espacio en el que despachar con clientes, arrendatarios o jornaleros, sin necesidad de hacerlos pasar a los espacios más privados ${ }^{133}$. También contempla la existencia de unas dependencias para huéspedes próximas al núcleo principal, pero individualizadas, con el fin

129 Ibn al-'Awwām, Libro de agricultura, I, p. 4.

130 Véase Navarro Palazón y Trillo San José (ed.), Almunias. Las fincas de las elites en el Occidente islámico: poder, solaz y producción.

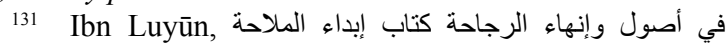
(Kitāb Ibdā' al-milāha wa-inhā' al-riŷāha fì uṣūl șinā'at al-filāha), fol. 49v.

132 Ibn Luyūn, في أصول وإنهاء الرجاحة كتاب إبداء الملاحة (Kitāb Ibdā' al-milāha wa-inhā' al-riŷāha fì uṣūl șinā'at al-filāḥa), fol. 49v.

133 Navarro Palazón y Jiménez Castillo, Siyāsa, pp. 216217. 
de preservar la intimidad de los que allí se alojaran, que suponemos se organizarían como un núcleo doméstico en torno a un patio central ${ }^{134}$ :

En la parte baja de la finca (bustān) [se construirá] una morada (manzil) con su [propia] puerta para huéspedes o para los amigos más íntimos, así como un zafariche (șahrîŷ). Estará rodeado de árboles para que quede oculto a quien desde arriba lo mire. Todos los aposentos [se construirán] en uno o dos lugares [de la finca] que estén sin ocupar, y quedarán ocultos y protegidos ${ }^{135}$.

Otro elemento singularizado con respecto a la casa y sobre el que, efectivamente, existen algunos testimonios documentales, arqueológicos e incluso iconográficos, es la torre residencial (que Ibn Luyūn llama burŷ suknà), en donde seguramente se combinaba este uso con el defensivo ${ }^{136}$. La recomendación de este autor acerca de la conveniencia de proteger las residencias campestres con una torre creemos que debe ser situada en su contexto cronológico, es decir, a comienzos del siglo XIV, cuando existían fundados temores a las incursiones cristianas enemigas a las ciudades de al-Andalus. Esta situación política era muy diferente de la existente en época califal, lo que explicaría la ausencia de este tipo de fortalezas asociadas a las almunias que conocemos por las fuentes escritas y arqueológicas del entorno de la Córdoba del siglo X. A partir del siglo XI su presencia debió de ser cada vez mayor, a medida que se incrementaba la inseguridad y el riesgo de algaras. Por ejemplo, en el valle del Ebro abundaban los pequeños establecimientos para unas pocas familias de campesinos que casi siempre contaban con torres, lo que explica la frecuencia de topónimos en burŷ, y a todos ellos se les denominó en las fuentes latinas posteriores a la conquista con el nombre de «almunias». A fines del siglo $\mathrm{XV}$, sabemos que las torres eran muy numerosas en el entorno de las ciudades nazaríes. En este sentido, Münzer escribe que la vega de Granada inmediatamente después de la conquista castellana «tiene huertos irrigados por acequias lle-

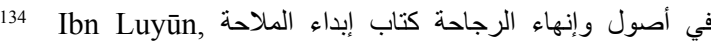
(Kitāb Ibdā' al-milāha wa-inhā' al-rî̀āha fì uṣūl sinā'at al-filāha), fol. 49v.

135 J. Eguaras no traduce la última frase. Tampoco recoge correctamente el término mawdi 'ayni, forma dual de mawdi i', 'lugar', al no incluir la 'ayn. Véase, Tratado de Agricultura (1988), p. 273.

136 Jiménez Castillo, "Fincas aristocráticas en la Murcia islámica", pp. 775 y 779; Jiménez Castillo, "Reales y rahales de la Murcia andalusí”, pp. 415-418. nos de casas y de torres, habitados durante el verano» ${ }^{137}$. Con relación a Baza, Hernando del Pulgar escribía lo siguiente: «avia mas de mill torres pequeñas, porque cada veçino de aquella çibdat que tenia en ella alguna parte, facia vna torre cercana a sus arboles; y aquello que le pertenecía regaua con açequias» ${ }^{138}$.

\subsection{Jardines y huertos ornamentales}

En torno a la residencia principal, se encuentra la parte más cuidada de la finca, que se denomina en términos jardineros «huerta de primor» ${ }^{139}$, área bien dotada de agua en la que conviven las plantas de puro ornato con los cultivos productivos que también tienen valor estético, como, por ejemplo, los cítricos. Es igualmente la zona verde más privada por su proximidad a la morada de los propietarios, por lo que también debe contar con cerca propia e incluso barrera vegetal que la aísle de otras áreas productivas de la finca y de los trabajadores que faenan en ellas. Así lo demuestran los ejemplos conservados en el Agdāl de Marrakech y en el Generalife, así como este texto de Ibn Wāfid, si nuestra interpretación es correcta ${ }^{140}$ :

Si quieres disponer un huerto (bustān), escoge un lugar adecuado de agua corriente, y que se halle en vecindad con las gentes para hacerles compañía (li-yakun qarīb ${ }^{a n}$ min masākin al-nās mușāhabatan la-hum), pues los huertos más hermosos (ahsan al-basātīn), más recreativos (anzah) y más útiles $\left(\right.$ anfa $\left.{ }^{\prime}\right)$ son los que están próximos $\left(\right.$ qarī $\left.b^{a n}\right)$ [a la vivienda]. Dispón la plantación de árboles altos como el plátano oriental, el ciprés, el pino, el sauce, el nogal, el avellano y otros semejantes junto a los muros del huerto (hawā'it al-bustān), hasta rodearlo completamente, y así será más bello (ahsana) [...]

El texto es dudoso puesto que no especifica si los huertos en cuestión se encuentran próximos a la casa, como nosotros nos inclinamos a pensar,

137 Münzer, Viaje por España y Portugal, p. 105.

138 Del Pulgar, Crónica de los señores Reyes Católicos, p. 339.Valo

139 En las almunias palatinas mejor conservadas, es posible distinguir de manera muy clara estas «huertas de primor», bien individualizados con su propia cerca, que en el Agdāl se corresponde con el recinto Dār al-Hanā' y, en el Generalife de Granada, con la Huerta Grande (Navarro Palazón y Puerta Vílchez, "Las huertas de Marrakech en las fuentes escritas", p. 287; Navarro Palazón y Garrido Carretero, "El paisaje periurbano de Marrakech", pp. 244 y 254; Navarro, Garrido y Almela, "The Agdal of Marrakesh. Part II", p. 31.

140 Ibn Wāfid, Compendio de Agricultura en Ibn Haŷŷâŷ, al-Muqni', pp. 35 ár. / 218-219 trad. 
o a la ciudad, lo que cambiaría la interpretación sustancialmente. No obstante, creemos que solo puede hacer referencia a la vivienda, pues de un huerto privado, aunque esté cerca de la urbe, no se podría afirmar que hace compañía a las gentes, ni tampoco es cierto que los huertos más hermosos y recreativos sean los más próximos a las medinas; sin embargo, estas características sí se pueden predicar de los huertos ajardinados que, de existir, siempre se situaban, lógicamente, junto a la vivienda de los propietarios.

Otra prueba indirecta de la atención que los geóponos ofrecen a los jardines y huertos ornamentales que junto con las extensiones dedicadas a la agricultura orientada al mercado formaban parte de las almunias, son las páginas en las que se ocupan de las plantas aromáticas por el placer que dan a los sentidos de la vista y del olfato $^{141}$.

Al-Tignarī diferencia los parrales que se plantaban sobre los andenes elevados o paseadores, que debían asociarse a armazones o emparrados para que se pudiera pasear por debajo de ellos, de los que se situaban en los jardines en hondo que los rodeaban llamados arriates (riyā cuales podían ser más bajos, ya que no estaban en espacios destinados a la circulación:

En las grandes almunias (al-munà al-kibār), las horcas o pértigas deben colocarse sobre los paseos de forma que sobrepasen la altura de las personas que circulen por ellos. En el caso de los jardines (riyāọat) y en aquellos lugares en los que nadie pasee por debajo de las parras (dawālī), estas quedarán a la altura de los que caminen a su alrededor por los andenes, dejando entre los racimos de uvas y la cabeza de quien vaya paseando un espacio no inferior a dos palmos

En relación con los cultivos y su utilización con vistas al esparcimiento, Abū l-Jayr explica en su tratado cómo manipularlos para conseguir formas insólitas. Estas esculturas vegetales eran otro de los elementos propios del huerto de primor situado en la zona cercana a la residencia principal de las almunias, aunque también flanquearían los caminos que, desde las puertas de

141 Véanse, para ello, Ibn Ḥaŷŷâŷ, al-Muqni' fì l-filāha, pp. 120-122 ár / 325-327 trad.; Ibn al- 'Awwām, Kitāb al-Filāha, I, pp. 248-252, 303-313; II, pp. 266-274 y 280-294; Ibn Bașāāl, Libro de Agricultura, pp. 163-172 ár. / 207-219 tr.; Ibn Luyūn, في أصول صناعة الفلاحة وإنهاء الرجاحة الملاحة كتاب إبدأ (Kitāb Ibdā' al-milāha wa-inhā' al-riȳāha fì uṣūl șinā'at al-filāha), fols 43r y 43v; Ibn Luyūn, Tratado de Agricultura (1988), cap. 140, pp. 173-176 ár. / 263-264 tr. Joaquina Eguaras; Ibn Bașșāl, Libro de Agricultura, pp. 181 ár. / 230-231 tr. la finca, se dirigían hacia la residencia principal. El autor sevillano dice al respecto ${ }^{142}$ :

A veces se componen formas insólitas (aškāl garība) en el huerto (bustān): una de ellas consiste en tomar una caña dura, limpiarla y hacer con ella unos cinchos torneados del grosor de la pierna del hombre $[. .$.$] , y se ponen de pie en diversos lugares$ del huerto [...], y se siembra a sus pies granos de índigo [...]. Cuando germinan, las ramas se enganchan a estos cinchos, se trenzan alrededor de ellos y los cubren hasta el punto de no verse la caña en absoluto, de forma que se ve una especie de columna que se eleva sobre las plantas verdes, especialmente cuando florece, y permanece así todo el período estival (al-șaíf kullu-hu) [...]. Lo mismo se hace (hakadā yuṣna') en los pabellones (al-qibāb) y en los corredores (al-aziqqa) hechos de caña (al-mașnū'a min al-qaṣab).

De la misma manera que los emparrados protegían del sol y del relente, para disfrutar apropiadamente de los huertos y jardines era conveniente la existencia de pabellones de madera o de obra en medio del área cultivada, normalmente sobre los andenes o paseadores que la cruzaban o contorneaban. A ellos se refiere Ibn Luyūn ${ }^{143}$.

En el centro del huerto (bustān) debe haber un pabellón (qubba) para poder sentarse y conversar (lil-muŷālasăt ${ }^{144}$, desde donde se pueda ver en todas las direcciones, pero en el que no se oiga lo que se dice para todo aquel que entre, y en el que no se deje de prestar atención a la persona que se dirija hacia él. Se deben poner rosas que trepen por [el pabellón], así como arrayán y todo lo que adorne la tierra de un huerto (arḍ al-bustān).

\subsection{Las infraestructuras hidráulicas}

Además de extensiones variables de espacios destinados a la agricultura de secano, las grandes fincas agrícolas, y las almunias en particular, también contaban de manera preferente

${ }^{142}$ Abū 1-Jayr, Kitāb al-Filāha, pp. 284-285 trad. / 137 ár.

143 Ibn Luyūn, في أصول و إنهاء الرجاحة كتاب إبداء الملاحة (Kitāb Ibdā' al-milāha wa-inhā' al-rî̀yāha fi uṣūl șinā'at al-filāha), fol. 49v.

144 J. Eguaras leyó al-muŷâlasāt en lugar de li-lmuŷālasāt, por lo que no consideraremos únicamente que el pabellón tenía asientos, sino también su utilidad. Así pues, la finalidad de este pabellón podría ser tanto un lugar de reunión donde poder conversar con familiares y amigos, como un espacio donde recibir a visitantes distinguidos. Véase en Kazimirski, I, p. 315 la Forma III de este verbo ŶLS: «Être assis en compagnie de quelqu'un». 
con áreas en las que se practicaban de manera intensiva los cultivos irrigados artificialmente. A diferencia de los sistemas hidráulicos vinculados a las alquerías campesinas, que se caracterizaban por el aprovechamient o de los recursos naturales y la economía de medios, los de las fincas de las élites disponían frecuentemente de infraestructuras relativamente costosas como evidencia de la capacidad de movilizar recursos por parte de sus dueños y de los beneficios esperados de esas inversiones. Se trata, sin embargo, de una hidráulica de rango medio puesto que en los libros de agricultura tampoco están presentes las grandes obras de ingeniería aplicadas al riego de las fincas de los sultanes, como, por ejemplo, las presas de derivación y acequias que daban servicio a las propiedades nazaríes del cerro del Sol en Granada ${ }^{145}$; los acueductos e ingenios asociados a la Alcazaba de Almería ${ }^{146}$ y a la Buhayra de Sevilla ${ }^{147}$; los albercones de las almunias califales como la Rummāniyya ${ }^{148} \mathrm{y}$ los del entorno del Castillejo de Monteagudo en Murcia ${ }^{149}$; diques como el que mandó construir en la garganta del Ciervo Ibrāhim ḅ. Hamušk, el señor de Segura y lugarteniente de Ibn Mardanīs ${ }^{150}$; o los complejos sistemas de galerías drenantes y estanques de las almunias del alfoz de Marrakech ${ }^{151}$.

En los tratados de agricultura son frecuentes las referencias a los diferentes elementos que permitían la captación, conducción y distribución de los recursos hídricos, acerca de los cuales Ibn Luyūn dice ${ }^{152}$ : «El zafariche (șahrî̀y) y el pozo (bir') [deben situarse] en lo más alto. O, en lugar del pozo, una acequia (sāqiya), cuyas aguas corran por la umbría».

145 Orihuela Uzal y García Pulido, "El suministro de agua en la Granada islámica".

146 Así lo refiere al- 'Uḍin. Véase, Nușūṣ, p. 85.

147 Valor Piechotta y Jiménez Hernández, "Las almunias de la Sevilla almohade: Buhayra y Aznalfarache", pp. 323342 .

148 Arnold, Canto García, y Vallejo Triano, Munyat ar-Rummānīyya.

149 Navarro Palazón y Jiménez Castillo, “Aproximación al estudio del Castillejo de Monteagudo", pp. 447-451.

150 Salvatierra y Gómez, "La presa de la Garganta del Ciervo", p. 309.

151 Navarro Palazón y Garrido Carretero, "El paisaje periurbano de Marrakech". Véanse estos y otros ejemplos en la monografía coordinada por Navarro Palazón y Trillo San José, Almunias. Las fincas de las élites en el Occidente islámico.

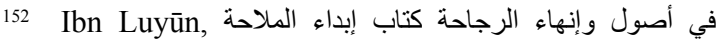
(Kitāb Ibdā' al-milāha wa-inhā' al-riŷāha fì ușūl sinā'at al-filāha), fol. 49v.
También al-Ṭignarī aconseja instalar las aceñas $(s a w \bar{a} n \bar{\imath})$ y los zafariches (sahārî̀y) en la parte más alta de la finca, con el fin de que posibilite el suministro de agua al resto de los huertos ${ }^{153}$ :

Lo primero que se necesita cuando se quiere poner en funcionamiento una aceña (sāniya) en la tierra que se desea regar, con el fin de que el agua de esta aceña atraviese toda esta tierra, es tener en cuenta cuál es la parte más alta del huerto (bustān), ya que, lo que se ponga en la parte más baja del mismo, no puede regar con sus aguas [el resto del huerto].

Ibn al- 'Awwām recoge una parte de ese fragmento para indicar en qué parte del huerto ( $\hat{y} a n-$ na) se ha de ubicar el pozo ${ }^{154}$ :

[...] que se procure hacer el pozo en lo más alto de

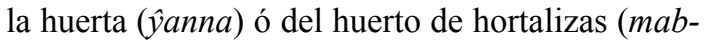
qala), cerca de la puerta ó en medio de él, si fuere posible; lo primero, para que de allí se pueda regar todo; y lo segundo, para que los que entraren, le tengan inmediato.

Obviamente, la posición elevada que recomiendan los geóponos tiene como objetivo facilitar el riego de los cultivos por gravedad. Esta particularidad se aprecia igualmente en Ibn Bașsāa l quien, en su estudio de los pozos, trata además otras cuestiones, como son el lugar idóneo para abrirlos, el modo de hacerlo dependiendo de la lejanía o cercanía a un río, el mes más propicio, los indicios que señalan si hay aguas subterráneas cerca del lugar elegido, el modo de montar las aceñas y la distancia que hay que respetar entre pozo y pozo para que no se vean afectados en el caudal o en la calidad de su agua ${ }^{155}$.

Los elementos destinados a la captación, conducción y almacenamiento de agua tenían una finalidad eminentemente agrícola y consuntiva. Pero también servían con fines hedonistas, como explica al-Tignarī: «[Y pasear] por los lugares por donde corre el agua y están los zafariches (saharrîy), por el sosiego (rāha) que esto [ofrece] $\rangle^{156}$. Así lo demuestran también las referencias de Abū l-Jayr y de al-Tignarī a algunas plantas que se cultivaban alrededor de los

153 Al-Ṭignarī, Kitāb Zuhrat al-bustān, pp. 94-95.

154 Véase, Ibn al-'Awwām, Libro de Agricultura, I, p. 144. Este autor dice que lo ha tomado "de Ibn Bașșāl y de otros".

155 Ibn Bașạāl, Libro de Agricultura, pp. 223-228 trad. / 174-179 ár. Parte de sus comentarios son recogidos por Ibn al-'Awwām. Véase el capítulo que este geópono dedica a la apertura de los pozos en los huertos ( $\hat{y} a n n \bar{a} t)$ y en las casas (diyār) en Libro de Agricultura, I, pp. 142-147.

156 Al-Ṭignarī, Kitāb Zuhrat al-bustān, pp. 94-95. 
lugares donde se hacía presente el agua, como es el caso del serbal (gubayrā'), un árbol utilizado normalmente como planta ornamental ${ }^{157}$.

Así, según Abū 1-Jayr ${ }^{158}$ : «Se planta alrededor de los aljibes (sahārîy), los ( $\bar{a} b \bar{a} r)$ y las acequias $(s a w \bar{a} q \bar{\imath})$ para que, cuando aparezca el que llegue a beber agua, quede frente a él y halle extraordinario el perfume de su flor y la belleza de su fruto». Y, citado por Ibn al- 'Awwām, al-Ṭignarī dijo que este árbol: «Se planta junto á los estanques (sahārîy) por su elegancia ó hermosura de su flor al desplegarse» ${ }^{159}$.

\subsection{La ganadería y los establos}

En las almunias se criaba ganado con fines comerciales y también para la explotación agrícola, pues los animales se empleaban principalmente para el tiro del arado, así como para la obtención de su estiércol que era fundamental para abonar los cultivos ${ }^{160}$. Casi todos los tratados agrícolas andalusíes dedican páginas enteras a citar los beneficios del estercolamiento, señalando cuáles son los mejores para cada cultivo y dando detalles de cómo se prepara y cuál es el momento óptimo para estercolar ${ }^{161}$. No obstante, solo se conservan datos zootécnicos en los tratados de Ibn Wāfid y de Ibn al- ${ }^{\circ} A w w a ̄ m{ }^{162}$. El primero se ocupa del ganado vacuno, lanar y caballar. También le interesa el tratamiento de sus enfermedades, la protección de plagas, el forraje conveniente, la elección de la dehesa y el tiempo del apareamiento. Otras especies de las que trata son las abejas, palomas, gallinas, ocas, pavos reales y perdices, a todas

157 Consúltese, para ello, Carabaza Bravo et al., Árboles y arbustos de al-Andalus, pp. 135-136.

158 Abū 1-Jayr, Kitāb al-Filāha, p. 266 trad. / 110 ár.

159 Ibn al- 'Awwām, Libro de Agricultura, I, p. 325.

160 Véase, a modo de ejemplo, Libro de Agricultura de Ibn al-'Awwām, I, cap. II, pp. 98-134.

161 Véase, Ibn al- 'Awwām, Libro de Agricultura, I, cap. II, pp. 98-134; Abū 1-Jayr, Kitāb al-Filāha, pp. 86-87 ár. / 249-250 tr.; Ibn Bașșāl, Libro de Agricultura, pp. 55-60 trad. / 49-53 ár.; al-Ṭignarī, Kitāb Zuhrat al-bustān, pp. 74-78; Ibn Luyūn, في أصول صناعة الفلاحة و إنهاء الرجاحة الملاحة كتاب إبدأ (Kitāab Ibdā' al-milāha wa-inhā' al-riŷāha fì uṣūl șinā'at al-filāha), fols. 7r-9r; Ibn Luyūn, Tratado de Agricultura (1988), pp. 6672 ár. / 208-211 tr.; Ibn Wāfid, Compendio de Agricultura en Ibn Haŷŷây, al-Muqni' fì l-filāha, pp. 10-11 y 31-32 ár. / 186-187 y 214- 215 tr.; Ibn Haŷŷâŷ, al-Muqni fi l-filāha, pp. 94-95 y 109 ár. / 292-294 y 312-313 tr.

162 El Kitāb Zuhrat al-bustān wa-nuzhat al-adhān de al-Ṭignarī (s. XI-XII) parece ser que constaba de una parte (maqāla) dedicada a la zootecnia y veterinaria, aunque no se ha conservado. Véase, para ello, García Sánchez, "El tratado agrícola del granadino al-Ṭignarī”, p. 290, así como de la misma autora, al-Ṭignarī, Abū 'Abd Allāh”, p. 458. les dedica un capítulo, ya que las considera útiles y beneficiosas (manāfi'), y dice que son: «muy habituales en las aldeas $(d i y \bar{a})$ y en los huertos (basātīn) $\rangle^{163}$. Hay que señalar que en dichos tratados, siguiendo los pasos de la geoponimia clásica, están completamente ausentes los animales exóticos o los de uso cinegético, que eran habituales en las fincas medievales de los soberanos; se trata, creemos, de otro indicio que confirma que estos no eran los destinatarios preferentes de estos libros aunque también se sirvieran de ellos como cualquier terrateniente.

Ibn Wāfid dedica muchas páginas a la cría de palomas en estos espacios productivos, e incluso la presenta de manera más extensiva que Ibn al-`Awwām. La palomina, su excremento, era muy codiciada entre los agricultores desde la Antigüedad. Como señala Julia Carabaza, los agrónomos latinos y del mundo bizantino ya hablaban de su beneficio por su alto poder calorífico y daban detalles de cómo debía utilizarse. Ibn Wāfid recoge tanto este saber antiguo como el propio de la cultura árabo-islámica, si bien, como concluye la autora, «aunque el agrónomo toledano quisiera dar un 'tinte clásico' a sus palabras, no hizo en realidad más que acudir a una fuente de su mismo entorno cultural [la fuente zoológico-literaria de mayor peso en la cultura islámica medieval: el Kitāb al-Hayawān de alŶāhiz] y redactar su capítulo sobre estas aves basándose en ella de manera casi exclusiva» ${ }^{164}$ :

Es necesario adquirir palomas y servirse de ellas constantemente en las labores agrícolas, dado su beneficioso estiércol para toda clase de frutos y tierras, [...] las palomas son, pues, utilísimas (rafq katīir) y reportan grandes beneficios (manāfi $^{\prime} \hat{y}$ amma $)^{165}$.

Posteriormente, y dentro del capítulo dedicado a los animales que se tienen en casas (buy $\bar{u} t)$ y huertas (basâttīn), Ibn al-'Awwām habla en primer lugar de las palomas, lo que denota la gran importancia que les confiere a estas aves dentro de la explotación agrícola. Según Carabaza, la existencia de pasajes idénticos entre este autor e Ibn Wāfid se debe al hecho de que usan las mismas fuentes y de que el autor sevillano utiliza la obra agrícola del toledano, aun-

163 Ibn Wāfid, Compendio de Agricultura en Ibn Haŷŷâŷ, al-Muqni' fì l-filāha, pp. 66-79 ár. / 259-275 tr.

164 Carabaza Bravo, "Las palomas en la agricultura andalusí”, pp. 241-251.

165 Ibn Wāfid, Compendio de Agricultura en Ibn Ḥaŷŷâŷ, al-Muqni' fì l-filăha, pp. 71 y 72 ár. / 265 y 266 tr. 
que nunca haga referencia a ello en su tratado ${ }^{166}$. Dice Ibn al-'Awwām:

Sábete, que las palomas son de grande utilidad; que hacen compañía; que su grangería es necesaria; y que su uso es indispensable en la agricultura por la utilidad que hay en su estiércol para todos los frutos $\mathrm{y}$ las tierras. Es la palomina indispensable, y no hay cosa que pueda suplirla, y una corta cantidad de ella hace que no sea necesaria mucha de otros estiércoles. Son pues muchas las comodidades, y muchos los provechos que hay en las palomas ${ }^{167}$.

Como se aprecia, ambos autores se muestran decididamente pragmáticos en sus consejos al subrayar explícitamente en sus obras la rentabilidad que las palomas pueden proporcionar. La información zoológica recogida en estos dos tratados agrícolas es valiosa, ya que da todo tipo de detalles relacionados con estas aves y su utilización en la agricultura, ampliando sensiblemente los datos proporcionados por los autores clásicos, pero aprovechando la información que necesitan en las diferentes fuentes que tienen a su alcance ${ }^{168}$.

Por su parte, Ibn Luyūn cita la torre-palomar (burŷ li-l-hamām) entre los elementos que debe tener la almunia, otro indicio de que la cría de estas aves era algo más que habitual en este tipo de fincas:

Y si [la finca] está dotada de una torre-palomar (burŷ li-l-hamām) y de una torreta habitable, todo ello la completará a la perfección (tamām) ${ }^{169}$.

Por ser una obra de carácter enciclopédico, Ibn al-'Awwām es quien ofrece más información sobre los animales presentes en las fincas, al dedicarle los 5 últimos capítulos de los 35 que componen su obra ${ }^{170}$. De esta manera, en el cap.

166 Junto a autores clásicos y al tratado de Ibn Wāfid, como decimos, Ibn al- 'Awwām también utiliza para elaborar su apartado sobre las palomas el Kitāb al-Hayawān de al-Ŷāḥiz, el libro de dietética de Abū Marwān Ibn Zuhr y la Agricultura Nabatea. Véase, Carabaza Bravo, "Las palomas en la agricultura andalusí", pp. 240, 245-246 y 251.

167 Ibn al-'Awwām, Libro de Agricultura, II, p. 701, cap. 34.

168 Carabaza Bravo, "Las palomas en la agricultura andalusí", pp. 252-255

169 Ibn Luyūn, في أصول وإنهاء الرجاحة كتاب إبداء الملاحة (Kitāb Ibdā' al-milāha wa-inhā' al-rîyâhha fì uṣūl sinā'at al-filāha), fol. 50r.

170 Los capítulos que tratan específicamente los animales son los 31-34. El 35 se ha perdido. Para el estudio de los animales domésticos, así como de otros de los que se sacaban provecho en las grandes fincas, según las informaciones obtenidas, entre otras obras, de los tratados geopónicos anda-
31 trata la crianza de animales (filāha al-ḥayawān), como el ganado vacuno (baqr), las ovejas ( $(\bar{a} m)$ y cabras (ma $a z)$. El cap. 32 está consagrado a la cría de los caballos (jayl), mulos (bigāl), asnos (hamīr) y camellos (abil). Todos ellos son utilizados por algunos de los motivos que ofrece el autor, principalmente porque sirven para las labores del campo y por la comodidad que ofrecen a la hora de hacer un viaje, como el Haŷŷ o peregrinación a la Meca. Posteriormente, recoge una serie de consideraciones zootécnicas y veterinarias acerca de este tipo de ganado. El cap. 33 trata del arte de la veterinaria (fann al-baytara) y el cap. 34, como acabamos de ver, de las aves (al-hayāwān al-țāyr) que normalmente se tienen en la casa [de campo] (buyūt), en las huertas (basâtīn) y en las aldeas o fincas (diy $\bar{a}^{\prime}$, pl. de daya ), como son las palomas (hammām), los gansos (iwazz), las cercetas (burak), los pavos reales (tawāwiss, pl. de țāwuws), las ga-

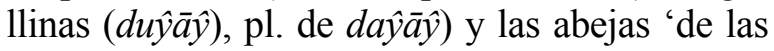
que dan miel' (nahl ma 'sal). Ibn al- 'Awwām dice en la presentación de este capítulo que se utilizan por el provecho (manfa ${ }^{\prime} a$ ) que se obtiene de ellas y también por su hermosura, elegancia o belleza $(\hat{y} a m \bar{a} l)$. De entre todas estas especies, se detiene en las gallinas ${ }^{171} \mathrm{y}$ en las abejas ${ }^{172}$, ya que son las más explotadas para su comercialización. El cap. 35 , aunque perdido, trata de los perros aptos para la caza (kilāb mubạh ittija $\underline{a} d i-h \bar{a} l i-l-s \underline{a y d}$ ) y para [guardar] los sembrados (zar') y el ganado (māšsi$y a)$, según anuncia el mismo autor en su prólogo. Los perros solo estaban permitidos en las grandes fincas por el beneficio que se obtenía de ellos, a pesar de considerarse un animal impuro ${ }^{173}$.

Por su parte, Ibn Luyūn, en la descripción del bustān, también habla de las bestias, centrándose específicamente en los establos y en el lugar idóneo donde se han de construir, así como de los elementos que se debe disponer en ellos, dis-

lusíes, consúltese Álvarez de Morales, "La zootecnia en los tratados agrícolas árabes”, pp. 81-91.

171 Ibn al- 'Awwām, Libro de Agricultura, II, pp. 706717.

172 Ibn al-'Awwām, Libro de Agricultura, II, pp. 717731.

173 Efectivamente, en el islam está prohibido tener perros, ya que se considera un animal impuro, pero está permitido si es para cazar o para guardar una finca, sus sembrados y su ganado, y siempre y cuando la propiedad esté en despoblado, sin otras viviendas alrededor. Por eso, Ibn al- 'Awwām habla de mubāh o lícito, cuando las menciona, entre las que se encontrarían las huertas ( $\hat{y} a n n \bar{a} t /$ basātīn), en donde el perro estaría permitido al cumplirse todos los requisitos de su tenencia. 
tinguiendo los espacios para las caballerías de los rediles para el resto del ganado ${ }^{174}$ :

El establo (iștabl) ha de construirse cerca de la puerta [de entrada a la finca] para [uso de] las bestias (dawābb), así como para los aperos de labranza $(\bar{a} l \bar{a} t)$. Y el edificio para el ganado menor o para el mayor (al-dār li-l-ganam aw li-l-baqar) se debe instalar en la parte más baja [de la finca] o cerca de donde puedan estar bajo vigilancia. Deberá estar rodeado de espacios cubiertos (buyūt) y techados (saqāyf) para protegerlos del frío y del viento impetuoso. Es fundamental que la casa de una alquería (al-dār bi-l-qarya $)^{175}$ tenga algorfas (guraf) y una fosa (hafra) para el estiércol, siempre que no se tenga el temor [de que cause algún incidente].

Es interesante destacar también en el fragmento anterior la mención a la fosa para el estiércol, puesto que la arqueología viene demostrando igualmente la proliferación de los campos de silos destinados a la producción de estiércol (compost) como abono para las tierras de cultivo, lo que algunos califican como una verdadera «revolución sucia» ${ }^{176}$. El desarrollo de la técnica del abonado, de la que también da testimonio la atención que se presta en estos libros a la palomina, como antes indicábamos, es un apartado fundamental en relación con el progreso técnico y el incremento de la productividad que de ello se derivaba.

\subsection{La organización del trabajo}

Los tratados geopónicos contienen también referencias muy interesantes acerca de la orga-

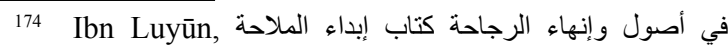
(Kitāb Ibdā' al-milāha wa-inhā' al-rî̀āha fị uṣūl șinā at al-filāha), fol. 50r. La arqueología apenas ha aportado información sobre los establos de las almunias; conocemos las caballerizas del Agdāl (Navarro, Garrido, Torres y Triki, "Agua, arquitectura y poder en una capital del Islam", pp. 39 y 40) y el Patio de las Caballerizas del Generalife (Bermúdez, "El Generalife", pp. 16 y 17), así como algunos ejemplos relacionados con las viviendas de una población mediana de carácter rural como Siyāsa (Navarro Palazón y Jiménez Castillo, Siyāsa, pp. 217 y 220); se trata efectivamente de dependencias situadas junto a la entrada de la casa, que comunican con el patio central y con el zaguán o directamente con la calle, y que cuentan con uno o varios pesebres.

175 Como ya se dijo, normalmente la qarya es un pequeño poblado habitado por campesinos independientes, aunque en este contexto debe entenderse como una de esas alquerías que formaban parte de la propiedad de un terrateniente. Véase, para ello, Ibn al-Jațīb, Lamha, pp. 24-25; Ibn al-Jațīb, Al-Ihạtạ, ed. B. Derradji, I, pp. 232-233; ed. 'Inān, I, p. 126.

176 Malalana y Morín, "La elaboración de compost en al-Andalus durante los siglos X-XI", pp. 118-126. nización del trabajo y la mano de obra con que se explotaban las fincas aristocráticas, un tema del que sabemos muy poco, más allá de alguna información que al respecto se puede espigar en textos de otra naturaleza como, por ejemplo, los formularios notariales o las colecciones de fetuas.

Tal y como dijimos anteriormente, al-Tignarī refiere que la musāqāt era una de las fórmulas empleadas en la explotación de las fincas a las que estaban destinados los libros de agricultura. Concretamente, se trata de un contrato de aparcería vinculado a tierras irrigadas, en donde se acuerda que el aparcero ponga todo el trabajo a cambio de una parte convenida de los frutos ${ }^{177}$. Para los cultivos de secano, el contrato tipo más extendido era el de la muzāra' $a$, donde el propietario de la finca concedía su tierra a un agricultor por un período determinado, en el que tenía lugar la siembra, el cuidado y la siega de la cosecha. La semilla la ponían ambos contratantes o uno solo, lo que establecía el tipo de muzāra' $a$ que se acordaba (a medias, al tercio, al cuarto y al quinto) $)^{178}$.

En los tratados geopónicos son frecuentes las referencias a las contrataciones de braceros o temporeros, aconsejando sobre las cualidades que conviene que tengan los trabajadores que se han de emplear en las fincas, así como los capataces encargados de dirigirlos. Al respecto, Ibn Luyūn señala que: «Para realizar las tareas [agrícolas] ( $\left.a^{\prime} m \bar{a} l\right)$, se deben elegir jóvenes que escuchen los consejos de los viejos» ${ }^{179}$. También al-Tignarī incluye en su obra un capítulo dedicado a «la elección de los trabajadores ('um$m \bar{a} l \bar{u} n$ ) y de los encargados de las explotaciones agrícolas $\left(\bar{u} k a l \bar{a}^{\prime}\right){ }^{180}$. Por su parte, Abū 1-Jayr en su «Capítulo relativo al gobierno de los jornaleros (juddām)» se ocupa extensamente de las aptitudes que ha de poseer el propietario de una finca para lidiar con éxito con sus empleados de manera que esta buena relación repercuta positivamente en su fortuna. Asimismo, da detalles de cómo deben ser estos trabajadores y de cómo se han de organizar para hacer su labor de una manera más eficiente ${ }^{181}$.

177 Véase, Vidal Castro, "La musāqā̄t", pp. 429-451.

178 Camarero Castellano, "El concepto del contrato de aparcería llamado muzāra'a”, pp. 181-198.

179 Ibn Luyūn, في أصول وإنهاء الرجاحة كتاب إبداء الملاحة (Kitāb Ibdā' al-milāha wa-inhā' al-riŷāha fì uṣūl șinā'at al-filāḥa), fol. 50r.

180 Al-Ṭignarī, Kitāb Zuhrat al-bustān, pp. 103-106.

181 Abū l-Jayr, Kitāb al-Filāha, pp. 139-142 ár. / 286- 
Del mismo modo, en su capítulo sobre las capacidades que conviene que tengan dichos agricultores, titulado "Qué hombres deben ser preferidos para hacer las labores, plantaciones y demás faenas rústicas», Ibn al- 'Awwām aconseja $^{182}$ :

que sean mozos y jóvenes por ser los mas fuertes, los mas alegres y expeditos, y los ménos perezosos para las faenas, y que los cavadores sean pares. Que el plantador de vides ú otros árboles, el inxertador y el escamondador sea joven de veinte á treinta años ó poco mas [...]. En las mangas [ó divisiones] no se han de poner juntos mas de quatro hombres, y si fueren mas, no han de juntarse á trabajar en un sitio para que [por aquella parte] no se adelante la labor.

Era habitual que los propietarios delegaran en un capataz el control y la vigilancia de los trabajadores durante el día. Este encargado debía darle el parte al finalizar cada jornada. Ibn al- ${ }^{\circ}$ Awwām al respecto dice ${ }^{183}$ :

El dueño de la posesión (șăhib al-day'a) con el capataz (nāzir) registrará las labores después de concluidas para tener conocimiento de quanto se hubiere trabajado; y aunque todo el dia haya estado ausente, conocerá la diligencia y esmero de los trabajadores en ausencia suya, ó su desidia y floxedad, si hubieren trabajado ménos [de lo que deben].

Cuando los terratenientes no estaban presentes en sus propiedades rústicas, a estos capataces se les confiaba la administración de sus fincas, según la recomendación de ${ }^{\circ} A_{t a b a}{ }^{\top} b$. Abī Sufyān a su encargado, que recoge Ibn al 'Awwām ${ }^{184}$ :

Cuida con esmero y vigilancia de mi pequeña posesión (șa ìr māllī) para que se haga grande; y no la tengas ociosa quando grande, para que no se haga pequeña ${ }^{185}$.

También Ibn Wāfid se ocupa de este tema en el capítulo titulado «Elección de los jornaleros» ${ }^{186}$, en el que, además de las recomendacio-

$288 \mathrm{tr}$.

182 Ibn al-'Awwām, Libro de agricultura, I, pp. 532-533.

183 Ibn al-'Awwām, Libro de agricultura, I, p. 534.

184 Ibn al- 'Awwām, Libro de agricultura, I, p. 4.

185 Para este hadiz, véase El Faïz, "L'apport des traités agronomiques hispanoarabes à l'histoire économique d'al-Andalus", p. 419.

186 Ibn Wāfid, Compendio de Agricultura en Ibn Haŷŷâŷ, al-Muqni' fì l-filāha, pp. 9-10 ár. / 184-185 trad. También se encuentra en la traducción castellana de esta obra. Véase, Millás Vallicrosa, "La traducción castellana", pp. 281-332. nes antes señaladas por los anteriores geóponos sobre la juventud que estos deben tener para que su labor sea óptima, aconseja:

Si hay un gran número de campesinos, no conviene que trabajen juntos en un mismo lugar porque, cuando lo hacen, hablan mucho y se instruyen mutuamente en diversas tretas y en cómo holgazanear en el trabajo, y debería existir, entonces, el mismo número de capataces que de campesinos. Deben agruparse de diez a seis, ni uno más ni uno menos y su trabajo ha de ser parejo. Colocarás a los que trabajen con el azadón de dos en dos, para que el holgazán trabaje tanto como el activo y constante, y que uno de ellos, de quien te fíes y al que des algo por ello, se encargue del otro ${ }^{187}$.

\subsection{Productividad y comercialización}

Los productos cultivados en las fincas que venimos tratando estaban destinados esencialmente al mercado, de manera que las explotaciones constituían una fuente de riqueza y prosperidad para sus dueños; por consiguiente, es normal que los tratados geopónicos dediquen mucha atención a plantas comerciales como la vid. Acerca de los cereales, sin embargo, no se extienden demasiado porque, según explican, los procedimientos son bien conocidos por todos.

Además, algunos autores relatan técnicas de procesamiento de algunas de esas plantas o de su conservación; por ejemplo, Ibn al-`Awwām, en su cap. 30, recoge una gran variedad de fuentes documentales relacionadas con la práctica industrial agrícola, entre las que se encuentran los geóponos Ibn Bașșāl, Abū 1-Jayr y al-Tignarī. Es un capítulo extensísimo, en el que trata, como él mismo señala, y entre otros temas, «Del modo de destilar el agua rosada, y de hacer el vinagre y el arrope de las uvas, el mostazado y semejantes. Señálense los meses del año y las operaciones de agricultura que es bueno hacer en cada uno de ellos» ${ }^{188}$

Como es lógico, una parte de la producción de las grandes fincas también era reservada para el autoconsumo, tanto de los cultivos más comunes como de otros singulares, cuyo valor residía

187 Esta última frase de Ibn Wāfid la tomaría años después Abū 1-Jayr. Véase esta cita en Kitāb al-Filāha, pp. 141 ár. / 287 tr.

188 Ibn al-'Awwām, Kitāb al-Filāha, II, pp. 388-428. Ibn Bașșāl, Libro de Agricultura, pp. 231 tr. /181 ár.; Abū 1-Jayr, Kitāb al-Filāha, pp. 173-185 ár. / 309-317 tr.; al-Ṭignarī, Kitāb al-Zuhrat, pp. 119-143. 
en la ostentación. Por ejemplo, Abū 1-Jayr explica algunos métodos para que ciertas plantas propias de verano se puedan disfrutar también en el invierno, de manera que tanto los dueños de las fincas como sus invitados se quedaran maravillados ${ }^{189}$ :

Para la ruda, el jazmín, la calabaza, el pepino, el pepinillo y otras clases de hortalizas de estío se hacen para ellas unos tejadillos de caña sobre pies de madera que las protegen del granizo, y se encienden diferentes fuegos alrededor, aunque lejos de ellas para transmitirles aire caliente. Esto solo se hace para que las hortalizas estivales puedan comerse en el invierno y esto cause admiración tanto a las personalidades ( $r$ ' $^{\prime} a \bar{a}^{\prime}$ ') como a los invitados (adya f), por lo insólito (yagribu bi-hi) que resulta.

No obstante, por su propia naturaleza, los libros de agricultura apenas contienen información sobre la segunda fase del proceso de explotación agrícola, que sería la comercialización y venta de los productos. Para encontrar datos al respecto, tenemos que acudir a otro tipo de fuentes documentales, como las jurídicas. Así, por ejemplo, una fetua recogida por al-Wanšarīsī (s. XVI), relativa a Ifrīqiya, pero emitida por el jurista andalusí Yahyà b. Umar (s. IX), da muestra de ello ${ }^{190}$ :

Se consultó a Yahyà: quien trae trigo a la ciudad no se puede saber si es para venderlo o para consumo propio. Respuesta. En este caso, dejaremos que lo transporte a su casa. Otra cuestión: ¿Y si alguien que se llevó trigo de su finca (manzil) ${ }^{191}$ a su casa, quiere venderlo, porque le hace falta su precio, y enseña en su mano una muestra por el zoco, y por esa muestra se lo compran los trigueros, a condición de medirlo en la casa para luego

189 Abū 1-Jayr, Kitāb al-Filāḥa, pp. 235 trad. / 67-68 ár. 190 Al-Wanšarīsī, al-Mìyār, VI, pp. 406-422. Este dictamen pertenece a un conjunto de fetuas que, según demostraron M. 'A. Makkī y E. García Gómez, constituye el más antiguo antecedente de los tratados de hisba (García Gómez, “Unas 'ordenanzas del zoco' del s. IX”, pp. 253-316, esp. p. 300). Aunque la cuestión formulada en esta fetua tuviera origen en Ifrīqiya, es de perfecta aplicación en al-Andalus, ya que, como dice E. García Gómez «el autor era andalusí, los problemas eran los mismos y el ambiente resultaba en aquella primitiva sazón muy análogo» (García Gómez, E., "Unas 'ordenanzas del zoco' del s. IX”, p. 261, nota 1).

191 Uno de los significados de manzil, además de vivienda, hospedería, parada y morada, es el de finca, que es el que E. García Gómez y M. `A. Makkī eligen en esta fetua por el contexto y como resultado de la traducción de la expresión: min mazili-hi ilà bayti-hi, 'de su finca a su casa'. Véase la aclaración realizada por el traductor, al respecto de este término, en García Gómez., "Unas 'ordenanzas del zoco’ del s. IX", p. 300 , nota 2 . trasladarlo a sus tiendas? Contestó Yahyyà: opino que no debe permitirse al vendedor que lo venda en su casa, y opino que debe trasladarlo a los zocos de los musulmanes.

A diferencia de los tratados de hisba, las fetuas relativas al alfaquí Yahyà b. Umar (s. IX), compuestas por preguntas y respuestas, distan mucho de las recomendaciones emanadas de los almotacenes en los tratados de los siglos XI y XII. En esta ocasión, ante la cuestión presentada, el dictamen emitido opta por no permitir que los dueños de las fincas vendan directamente en su casa el trigo que han obtenido en sus fincas, sino que deben hacer todas las gestiones comerciales en el mercado. Pero lo que ahora nos interesa de esta fetua es que documenta la figura del dueño de tierras que, además de sus fincas, posee una residencia en la ciudad en la que mora habitualmente y que comercializa los productos de su actividad agrícola en el mercado urbano. Es justamente el tipo de terrateniente que estaría muy interesado en la información que aportan los libros de agricultura para la adecuada explotación de sus propiedades.

\section{Síntesis}

Para situar adecuadamente los libros de agricultura en su contexto histórico es necesario que tratemos de aproximarnos, aunque sea brevemente, a la estructura de la propiedad de la tierra en el momento de su redacción, tarea que, por otro lado, no es sencilla debido a la escasez de estudios sobre el tema.

Parece probado que la primera «revolución» agrícola en al-Andalus arrancó con la llegada de los primeros pobladores orientales tras la conquista y se desarrolló durante la fase paleoandalusí. La introducción de nuevos cultivos y la expansión de la tecnología hidráulica asociada estuvo a cargo primordialmente de grupos de campesinos unidos por lazos clánico-tribales, desprovistos de conexiones decisivas con el poder, los cuales colonizaron amplios sectores del medio rural e implantaron sistemas productivos, en los que predominaba el dominio colectivo ${ }^{192}$. Asentados en alquerías, estos campesinos practicaban una agricultura orientada al autoabastecimiento que generaba los excedentes mínimos,

192 Guichard, Al-Andalus. Estructura antropológica, pp. 338-458; Barceló, "El diseño de los espacios irrigados"; Barceló, Kirchner y Navarro, El agua que no duerme, pp. 38-46; Kirchner, Virgili y Antolín, "Un espacio de cultivo urbano", pp. 13-14; Trillo San José, Agua, tierra y hombres, pp. 43-48. 
con el fin de evitar su captura por parte del Estado. Junto al modelo productivos asociado a esas comunidades campesinas, las crónicas acreditan la existencia de grandes fincas situadas en el entorno de las ciudades, pertenecientes a las familias más poderosas, así como de propiedades particulares que se extendían por áreas más alejadas, lo que sin duda reducía su valor relativo.

En el otro extremo temporal, la estructura de la propiedad de la tierra en época nazarí, que conocemos mejor gracias a una documentación de archivo árabe y castellana sensiblemente más rica, presenta cambios sustantivos. En torno a las ciudades predominaban las fincas aristocráticas, así como las alquerías y aldeas, algunas de las cuales estaban habitadas por campesinos independientes y otras eran propiedad de algún señor. En las zonas plenamente rurales, también la propiedad gentilicia parece haber sido minoritaria frente a la privada, detectándose la existencia de campesinos enriquecidos e incluso de terratenientes ajenos al vecindario que emprendían cultivos comerciales ${ }^{193}$. Según Carmen Tri1lo, el cambio de una estructura de la propiedad predominantemente gentilicia, como sería la de los primeros siglos, a otra aldeana y esencialmente privada, pudo deberse a factores que favorecieron la pérdida de vigor de los lazos de parentesco como, quizás, el desarrollo comercial y la presión castellana.

Entre ambos extremos, hay efectivamente indicios que deben ser tenidos en consideración, con relación a ese proceso de cambio en el dominio de la tierra, que seguramente no fue progresivo ni homogéneo ${ }^{194}$. A partir del s. X, se detecta el incremento de la propiedad privada en el medio rural e, incluso, el paso a manos de particulares de algunas tierras comunitarias, según parece desprenderse, por ejemplo, de formularios notariales andalusíes, como los de Ibn al-'Aț̣āir (m. 1009), Ibn Mugìt (m. 1067) y alŶazīrī (m. 1089), en los que abundan los modelos destinados a negocios entre particulares y están del todo ausentes referencias a propiedades comunitarias relacionadas con el linaje o de cualquier otra índole. En los Maḍāhib alhukkām, colección de fetuas que recoge casos relacionados con la actividad judicial del cadí 'Iyāọ (1083-1149), abundan las referencias a la progresión de la propiedad privada, hasta el

\footnotetext{
193 Trillo San José, Agua, tierra y hombres, pp. 200, 207, 220, 244 y 245.

194 Trillo San José, Agua, tierra y hombres, pp. 180 y
} 181. punto de que Delfina Serrano concluye que «la propiedad es individual en la práctica totalidad de los casos» ${ }^{195}$. Así pues, aunque siguen existiendo las tierras comunitarias (mawāt), estas se limitan a ciertas áreas (harim) que circundan las alquerías y, en cualquier caso, se encuentran sometidas a la presión de algunos vecinos que pretenden apropiárselas, incluso cuando se trata de prados dedicados al pastoreo intensivo del ganado ${ }^{196}$. Asimismo, está registrada en estas sentencias la expansión de los cultivos privados sobre tierras muertas, a veces yermas por abandono, mediante usucapión o prescripción adquisitiva (hiy $\bar{a} z a)^{197}$, lo que demuestra que este fue uno de los medios empleados para la formación de propiedad particular. También la documentación cristiana muestra indicios en este sentido; así, por ejemplo, en el momento previo a la conquista de mediados del s. XIII, la propiedad era totalmente privada en la huerta de la Murcia andalusí, a juzgar por la información derivada del Repartimiento ${ }^{198}$. De acuerdo con los datos que extrae de la literatura jurídica, Vincent Lagardère detecta que, entre los siglos XII y XIII, una parte de los campesinos en busca de nuevas tierras se habrían apropiado y repartido las tierras comunes de su alquería o los bienes del Estado, conservando al mismo tiempo el uso y mantenimiento colectivo de los sistemas de riego provenientes de la captura de arroyos, ríos o manantiales naturales, una transformación que orientaba la agricultura hacia cultivos de regadío especulativos e intensivos con mayor valor añadido ${ }^{199}$. Por su parte, Lucie Bolens también detectó la proliferación de la pequeña propiedad privada, a partir del final del califato y durante el periodo de los reinos de taifas, pero no lo atribuyó a la iniciativa campesina, como lo hiciera Lagardère, sino al Estado y a los terratenientes, mediante la venta masiva de propiedades y la

195 Ibn 'Iyāḍ, Madāāhib al-hukkām, pp 56, 62 y 63.

196 Ibn 'Iyāḍ, Ma âāhib al-ḥukkām, pp. 66 y 67.

197 Por ejemplo, un hombre había comprado «propiedades antiguas y nuevas, dentro y fuera de la muralla de Málaga, a saber: casas, tierras incultas, una plantación de higueras y otros frutales, campos cultivados ('amira) y deshabitados ( $g \bar{a} m i r a)$, y demás propiedades que constaban a su nombre en la Cora de Rayya hasta los alfoces ( $a h w \bar{a} z)$ más alejados de dicha ciudad y sus zonas más extremas», tierras que él mismo explotaba y cuidaba. (Ibn 'Iyāạ, Ma dāhib al-ḥukkām, p. 277).

198 Manzano Martínez, "Aproximación a la estructura de la propiedad", pp. 61-75; Manzano Martínez, “Aproximación a la problemática histórica", pp. 489-507.

199 Lagardère, "Terres communes et droits d'usage", p. 53. 
parcelación del suelo a favor de los colonos instalados en el terreno y personalmente interesados en el rendimiento de sus cultivos ${ }^{200}$. El declive de los derechos de carácter colectivo basados en sistemas de linaje a favor de la propiedad privada de la tierra tendría que ver con la decadencia de la estructura social clánica a partir del siglo $\mathrm{X}$, paulatinamente suplantada por una sociedad «aldeana», basada cada vez más en la familia nuclear y las relaciones de vecindad en el ámbito rural, según parece derivarse de los trabajos de Guichard ${ }^{201}$. Cabe suponer que una de las causas de este proceso sería el triunfo del Estado omeya en el siglo X, cuando se inició una transición compleja que finalizó con la imposición, hacia la época del califato, de la formación social islámica caracterizada por la hegemonía de lo privado y del mundo urbano $^{202}$. Seguramente, también tendrían consecuencias en este sentido los efectos derivados de la primera «revolución» verde: la agricultura intensiva, irrigada y acompañada de nuevos productos fue capaz de generar «local surpluses», que comenzaron a fluir hacia el Estado y hacia las elites urbanas, de manera que el aumento de los rendimientos agrícolas incrementó el comercio, la acuñación de moneda, la demanda de bienes de consumo y, en última instancia, la creación de nuevos espacios de cultivo ${ }^{203}$. El ejercicio de los derechos de propiedad sobre las fincas agrícolas también acabaría alimentando el proceso de privatización y concentración pues, dado que los dueños podían determinar el uso de las tierras decidiendo sobre la manera de cultivarlas, muchas

200 Bolens, Agronomes andalous, pp. 2-14.

201 Guichard, Al-Andalus. Estructura antropológica, pp. 332-338; Guichard, Les Musulmans de Valence, I, pp. 227 y 228; Guichard, Al-Andalus frente a la conquista, pp. 291-301. Esta situación quizás no era homogénea en todo el territorio andalusí; por ejemplo, en las islas Baleares, tardíamente colonizadas por los musulmanes a partir de la segunda mitad del s. IX, todavía en el primer tercio del siglo XIII «el patrón de asentamiento andalusí -basado en territorios de control clánico y en la asociación a espacios de cultivo irrigado, compartidos cuando su tamaño lo permite, o de disfrute exclusivo por parte de un grupo clánico, cuando no superan las 2 ha de superficie, y dejando extensas zonas de intersticio, yermas, probablemente de aprovechamiento silvo-pastoral- es un patrón estrictamente tribal y clánico, donde el concepto de posesión individual de tierras no tiene cabida» (Kirchner, "Huṣūn y alquerías", p. 261).

202 Acién Almansa, "Poblamiento y fortificación", p. 142.

203 Glick, Islamic and Christian Spain, pp. 61-62. de ellas irían a parar finalmente a manos de aquellos que lograran obtener mayor productividad ${ }^{204}$.

En este contexto de transformación de la estructura de la posesión de la tierra, la eclosión de los libros geopónicos en el siglo XI está estrechamente relacionada con la proliferación de propietarios fundiarios particulares, principalmente ciudadanos con recursos y formación suficientes, interesados en los beneficios crecientes que proporciona una agricultura basada en los adelantos técnicos de la «revolución verde» y en un mercado en expansión debido al desarrollo demográfico y urbano. Ellos y no los sultanes serían, en términos generales, los destinatarios de una literatura que no estaría asociada a la multiplicación de patrocinadores reales con el establecimiento de las taifas, sino a la eclosión de dicho estamento de terratenientes. Al igual que sucedió en la Europa occidental durante la «revolución económica» del siglo XI, las medinas andalusíes en proceso de crecimiento pudieron absorber la población desplazada del campo, gracias al desarrollo del comercio y del artesanado incentivados por el incremento en la demanda de manufacturas y bienes de consumo por parte de unos grupos relativamente acomodados. Entre ellos se hallaban los propietarios de tierras enriquecidos e, incluso, los propios sultanes, los cuales se beneficiaron precisamente del control de una parte de la producción agrícola orientada al mercado. Por consiguiente, los tratados de agricultura constituyen una fuente de información histórica muy valiosa acerca de las características y la organización del trabajo en un modelo de haciendas que estaba eclosionando precisamente en el momento en que se redactaron esos libros, como resultado de los cambios profundos que estaban teniendo lugar en relación a la propiedad de la tierra y al sistema productivo en general.

\section{Fuentes geopónicas}

\section{Tratados}

Abū 1-Jayr, Kitāb al-Filāha. Tratado de agricultura, ed. y trad. Julia María Carabaza Bravo, Madrid, ICMA, 1991.

Columela, Lucio Junio Moderato, Los doce libros de agricultura, trad. Juan María Álvarez de Sotomayor y Rubio, Madrid, imprenta de D. Miguel de Burgos, 1824.

204 Watson, Innovaciones en la agricultura, pp. 234236. 
Ibn 'Abdūn, Sevilla a comienzos del siglo XII. El tratado de Ibn 'Abdūn, trad. y estudio de Emilio García Gómez y Évariste Lévi-Provençal, Sevilla, Biblioteca de temas sevillanos, 1992.

Ibn al- 'Awwām, Kitāb al-Filāha. Libro de agricultura, ed. y trad. Josef Antonio Banqueri, 2 vols., Madrid, 1802 (ed. facs. con estudio preliminar y notas por J. Esteban Hernández Bermejo y Expiración García Sánchez), Madrid, Ministerio de Agricultura, 1988.

Ibn Bașșāl, Kitāb al-Qaṣd wa-l-bayān: Libro de agricultura, ed. y trad. José María Millás Vallicrosa y Mohamed ‘Azīmān. Tetuán, 1955 (ed. facs. con estudio preliminar por Expiración García Sánchez y J. Esteban Hernández Bermejo), Granada, Sierra Nevada 95, 1995.

Ibn Haŷŷây, al-Muqni fì l-filāha, ed. S. Ŷarrār y Abā Șafīya, 'Ammān: Maŷma' al-Luga al-'Arabiyya al-Urduniyya, 1982. (La obra de Ibn Wāfid está incluida dentro de esta, en las pp. 6-84).

Ibn Haŷŷây, al-Muqni fì l-filāha, intr., est. y trad. con glosario por Julia María Carabaza Bravo, (Tesis Doctoral leída en 1987), Universidad de Granada, Departamento de Estudios Semíticos, 1988, [en línea], disponible en: <https://digibug.ugr.es/ handle/10481/5929>, [consultado el 06/02/2020].

Ibn Luyūn, كتاب إبداء الملاحة و إنهاء الرجاحة في أصول/20201 (Kitāb Ibdā' al-milāha wa-inhā' alriŷāha fì uṣūl șinā'at al-filāḥa) [Manuscrito], Almería, 1348, [en línea], disponible en: Manuscripta: $<$ https://csic-primo.hosted.exlibrisgroup. com/primo-explore/fulldisplay?docid $=34 \mathrm{CSIC}$ ALMA_DS21130141780004201\&context $=$ L\& vid=34CSIC_VU1\&search_scope $=$ CAT_BIB $\mathrm{scope} \& \mathrm{tab}=$ default tab\&lang $=$ es_ES $>$, [consultado el 03/02/2020].

Ibn Luyūn, Kitāb Ibdā' al-milāha wa-inhā' al-riŷāḥa fi ușūl șinā'at al-filāha, ed. y trad. por Joaquina Eguaras como Tratado de agricultura, Patronato de la Alhambra y el Generalife, Granada, 1975.

Ibn Luyūn, Kitāb Ibdā' al-milāha wa-inhā' al-rî̀āḥa fi uṣūl șinā'at al-filāha, ed. y trad. por Joaquina Eguaras como Tratado de agricultura, Patronato de la Alhambra y el Generalife, Granada, D.L. 1988. (Publicaciones del Patronato de la Alhambra, 2).

Kitāb fì tartīb awqāt al-girāsa wa-l-magrusāt. Un tratado agrícola andalusí anónimo, ed. y trad. Ángel Custodio López y López, Granada, 1990.

Al Țignarī, Kitāb Zuhrat al-bustān wa-nuzhat aladhān: Esplendor del jardín y recreo de las mentes, ed. Expiración García Sánchez, Madrid, CSIC, 2006.

\section{Calendarios}

'Arīb b. Sa ${ }^{\circledR} \overline{1} \mathrm{~d}$, Le Calendrier du Cordoue, Reinhart Pieter Anne Dozy (ed.), Charles Pellat (trad./anot.), Leiden, E. J. Brill, 1961.

Ibn 'Āṣim, Kitāb al-anwā' wa-l-azmina - al-qawl fi l-šuhūr - (tratado sobre los anwā' y los tiempos capitulo sobre los meses), por Miquel Forcada (est., trad. y ed. crítica), Madrid, CSIC /ICMA, 1993.

Risāla fì awqāt al-sana: Un calendario anónimo andalusí, ed. y trad. María Ángeles Navarro, CSIC, Granada, 1990.

\section{Fuentes histórico-geográficas}

Ajbar Machmuâ, trad. y anot. E. Lafuente Alcántara, Madrid, 1867, [en línea], disponible en: <http:// www.bibliotecavirtualdeandalucia.es/catalogo/ consulta/registro.cmd?id $=100088>$, [consultado el 28/02/2020].

Ibn al-Abbār, al-Takmila, ed. Francisco Codera, Madrid, Biblioteca Arabico-Hispana V-VI, 18861889, [en línea], disponible en: <http://bdh-rd.bne. es/viewer.vm?id $=0000045489$ \&page $=1>$, [consultado el 28/02/2020].

Ibn Bassām, Al-dajīra fì mahāsin ahl al-Ŷazīra, ed. Iḥsān 'Abbās, 4 vols. Beirut, 1997, [en línea], disponible en: <https://archive.org/details/zakhera mahasen_jazeera/mode/1up $>$ [consultado el 10/02/2020].

Ibn al-Jaṭīb, Al-Iḥāta fì ajbār, Muḥammad 'Abd Allāh 'Inān (ed.), El Cairo, Maktabat al-Janŷ̀1, 19731977, 4 vols.

Ibn al-Jațīb, Al-Iḥạța fí ajbār, Bouziani Derradji (ed.), Argel, Dār al-Amal li-l-dirāsāt, Ministère de la Culture, Fonds National pour la Promotion et le Développement des Arts et des Lettres, 2009.

Ibn al-Jațīb, Lamḥa al-badriyya fì ajbār al-dawla al-nașriyyya, Beirut, 1980.

Ibn al-Jațīb, Historia de los reyes de la Alhambra: el resplandor de la luna llena (Al-Lamha al-badriyya), Estudio preliminar por Emilio Molina López; traducción e introducción de José María Casciaro Ramírez, Granada, Universidad, 1998.

Ibn Șaḥīb al-Salāt, al-Mann bi-l-imāma, Ambrosio Huici Miranda (est. prelim., trad. e índ.), Textos Medievales, 24, Valencia, Anubar, 1969.

Al-Jušanī: Historia de los jueces de Córdoba por Aljoxaní, Textos árabes y trad. Julián Ribera, Madrid, Centro de Estudios Históricos, 1914.

Münzer, Jerónimo, Viaje por España y Portugal. Reino de Granada, intr. Manuel Espinar Moreno, Granada, 2008.

Simonet, Francisco Javier, Descripción del reino de Granada bajo la dominación de los naseritas: sacada de los autores árabes y seguida del texto in- 
édito de Mohammed ebn Aljatib, Madrid, Imprenta Nacional, 1860.

Al-Ṭurțūšì, Muhammad Ibn al-Walīd, Lámpara de los príncipes Kitāb Sirāj al-mulūk, trad. Maximiliano Alarcón, Madrid, Maestre, 1931.

Al- 'Ud̆rī, Nușūṣ 'an al-Andalus min Kitāb Tarșī al-ajbār wa-tanwī' al-ātāar, wa-l-bustān fì garā'ib al-buldān wa-l-masālik ilà ŷam̄̄' al-mamālik, ed. 'A. 'A. al-Ahwānī, Madrid, Instituto de Estudios Islámicos, 1965.

\section{Fuentes jurídicas}

Ibn Ab̄̄ Zayd al-Qayrawān̄̄, al-Risāla: La Risāla ou Epître sur les éléments du dogme et de la loi de l'Islam selon le rite mâlekite, L. Bercher (trad./ed. / not. / index), Argel, 1983.

Ibn al- Atțāar, Kitāb al-watāà'iq wa-l-siŷillāt, ed. Pedro Chalmeta y Federico Corriente, Formulario notarial hispano-árabe, por el alfaquí y notario cordobés Ibn al-'Atțār (s. X), Madrid, 1983.

Ibn al- Atțār, Formulario notarial y judicial andalusí, Pedro Chalmeta y Marina Marugán (intr./est. / trad. anot.), Madrid, 2000.

Ibn Habīb, Kitāb al-Wādiḥa, Fragmentos extraídos del Muntajab al-aḥkām de Ibn Abī Zamanīn (m. 399/1008), María Arcas Campoy (intr. / est. crít. / trad.), CSIC, Madrid, 2002, Fuentes Arábico-Hispanas, 27.

Ibn 'Iyāḍ, Madāhib al-ḥukkām fì nawāzil al-ahkām (La actuación de los jueces en los procesos judiciales), trad. y est. Delfina Serrano, Madrid, CSIC, 1998.

Al-Wanšarīsī, al-Mi yār al-mugrib wa-l-yamī' almu'rib 'an fatāwà ahl Ifrīqiya wa-l-Andalus wa-lMagrib, M. Haŷŷ̄̄ (ed.), 13 vols., Rabat, 1981-1983.

\section{Estudios}

Acién Almansa, Manuel, "Poblamiento y fortificación en el sur de al-Andalus. La formación de un país de huușūn", III Congreso de Arqueología Medieval Española, Oviedo, Universidad de Oviedo, 1988, t. I, pp. 135-150.

Álvarez de Morales, Camilo, "La zootecnia en los tratados agrícolas árabes”, Ciencias de la Naturaleza en al-Andalus, I (1990), pp. 81-91.

Álvarez de Morales, Camilo, “Agrónomos andalusíes y sus legados", en Fernando Nuez Viñals (ed.), La herencia árabe en la agricultura Occidente, y el bienestar de Occidente, Valencia, Fundación la Huella Árabe, Universidad Politécnica de Valencia, 2002, pp. 9-69.

Álvarez de Morales, Camilo y Carabaza Bravo, Julia María, “Ibn Wāfid, Abū 1-Muțarrif”, en Jorge Lirola (dir.) y José Miguel Puerta Vílchez (ed. lit.), Biblio- teca de al-Andalus, Almería, Fundación Ibn Tufayl de Estudios Árabes, 2007, vol. 5, pp. 565-569.

Arnold, Felix, Canto García, Alberto y Vallejo Triano, Antonio, Munyat ar-Rummānīyya. Die Gartenanlagen (Madrider Beiträge 39), Wiesbaden, Reichert, 2019.

Azuar, Rafael, "Formación de la ciudad islámica en el Sharq Al-Ándalus (siglos IX-X/III-IV)", Al-Andalus, país de ciudades/Actas del Congreso celebrado en Oropesa (Toledo), del 12 al 14 de marzo de 2005, Toledo, Diputación Provincial de Toledo, 2008, pp.79-105.

Barceló, Miquel, "El diseño de los espacios irrigados en Al-Andalus: un enunciado de principios generales", El agua en zonas áridas: Arqueología e Historia. I Coloquio de historia y medio físico, vol. I, Almería, Instituto de Estudios Almerienses, 1989, pp. XV-XLIX.

Barceló, Miquel, Kirchner, Helena y Navarro, Carmen, El agua que no duerme. Fundamentos de la arqueología hidráulica andalusí, Granada, El legado andalusí, 1996.

Barceló, Miquel, "De Mulk a Mulūk: esperando a los al-murābițūn", en Carlos Laliena y Juan F. Utrilla (ed.), De Toledo a Huesca. Sociedades medievales en transición a finales del siglo XI (1080-1100), Zaragoza, 1998, pp. 61-66.

Benaboud, Mhammad, "La economía de al-Andalus publicado en los reinos de Taifas, Al-Andalus en el siglo XI”, Historia de España, Colección Ramón Menéndez Pidal, tomo VIII, Madrid, Espasa-Calpe, 1994, pp. 229-272.

Bermúdez Pareja, Jesús, "El Generalife después del incendio de 1958", Cuadernos de la Alhambra, 1 (1965) pp. 9-40.

Beutler, Corinne, "Un chapitre de la sensibilité collective: la littérature agricole en Europe continentale au XVI ${ }^{\mathrm{e}}$ siècle", Annales. Économies, Sociétés, Civilisations, 28, 5 (1973), pp. 1280-1301.

Bolens, Lucie, Les méthodes culturales au Moyen Âge d'après les traités d'agronomie andalous. Tradition et technique, Ginebra, Tesis doctoral inédita, 1974.

Bolens, Lucie, "La révolution agricole andalouse du $\mathrm{XI}^{\mathrm{e}}$ siècle", L'Andalousie du quotidien au sacré, $X I^{e}$-XIII ${ }^{e}$ siècles, Aldershot-Hampshire, Collected Studies, CS 337 (1990), pp. 9-29 (reedición del artículo publicado en Studia Islamica, 47 (1978), pp. 121-141).

Bolens, Lucie, Agronomes andalous du Moyen-Age, Ginebra-París, Librairie Droz, 1981.

Bosch Vilá, Jacinto, "El siglo XI en al-Andalus. Aspectos políticos y sociales. Estado de la cuestión. Perspectivas", Actas de las Jornadas de Cultura Árabe 
e Islámica (1978), Madrid, Instituto Hispano-Árabe de Cultura, 1981, pp. 183-195.

Brufal, Jesús, "La Lleida de secano en los siglos XI-XIII: nueva interpretación del territorio", en Antonio Malpica (ed.), Análisis de los paisajes históricos. De al-Andalus a la sociedad feudal, Granada, Alhulia, 2009, pp. 241-265.

Camarero Castellano, Inmaculada, "El concepto del contrato de aparcería llamado muzāra'a, según los juristas malikies de al-Andalus (s. VIII-XV)", Boletín de la Asociación Española de Orientalistas, XXXVIII (2002), pp. 181-198.

Camarero Castellano, Inmaculada, "Las labores vivificadoras como medio de adquisición de la tierra muerta", Ciencias de la Naturaleza en al-Andalus. Textos y Estudios, VII (2004), pp. 179-193.

Camarero Castellano, Inmaculada, Sobre el 'estado de yā'iha'. Teoría y práctica jurídica de la calamidad rural y urbana en al-Andalus (ss. VIII-XV), Sevilla, Editorial Universidad de Sevilla, 2015.

Carabaza Bravo, Julia María, "La edición jordana de al-Muqni" de Ibn Haŷŷâŷ. Problemas en torno a su autoría”, Al-Qanțara, 11 (1990), pp. 71-81.

Carabaza Bravo, Julia María, "El agua en los tratados agronómicos andalusíes", Anaquel de Estudios Árabes, V (1994), pp. 19-38.

Carabaza Bravo, Julia María, "Las palomas en la agricultura andalusí”, Dynamis, 21 (2001), pp. 233-256, [en línea], disponible en: <https:/www.raco.cat/ index.php/Dynamis/article/viewFile/92576/117791>, [consultado el 03/11/2019].

Carabaza Bravo, Julia María, y García Sánchez, Expiración, "Estado actual y perspectivas de los estudios sobre agronomía andalusí”, en Fátima Roldán Castro e Isabel Hervás Jávega (coords.), El Saber en al-Andalus. Textos y estudios III (2001), Sevilla, Universidad de Sevilla, pp. 101-118.

Carabaza Bravo, Julia María, García Sánchez, Expiración, Hernández Bermejo, J. Esteban y Jiménez Ramírez, Alfonso, Árboles y arbustos de al-Andalus, Estudios Árabes e Islámicos: Monografías. 8, Madrid, CSIC, 2004.

Carabaza Bravo, Julia María, "Ibn Haŷŷāŷ al-Lajmī, Abū 'Umar”, en Jorge Lirola (dir.) y José Miguel Puerta Vílchez (ed. lit.), Biblioteca de al-Andalus, Almería, Fundación Ibn Tufayl de Estudios Árabes, 2004, vol. 3, pp. 382-385.

Carabaza Bravo, Julia María, "Fuentes escritas y orales del tratado agrícola de Ibn Haŷŷâŷ", en Clara María Thomas de Antonio y Antonio Giménez Reíllo (coords.), El saber en Al-Andalus. Textos y estudios, IV: Homenaje al profesor D. Pedro Martínez Montávez, 2006, Sevilla, Editorial Universidad de Sevilla, pp. 73-94.
Carabaza Bravo, Julia María, “al-Išbīlī, Abū 1-Jayr”, en Jorge Lirola (dir.) y José Miguel Puerta Vílchez (ed. lit.), Biblioteca de al-Andalus, Almería, Fundación Ibn Tufayl de Estudios Árabes, 2009, vol. 6, pp. 395-399.

Carballeira Debasa, Ana María, "Living on the margins of society: coping with poverty in al-Andalus", en Amélia Aguiar Andrade et al. (eds.), Inclusão e Exclusão na Europa Urbana Medieval / Inclusion and Exclusion in Medieval Urban Europe, Lisboa, Instituto de Estudos Medievais (Universidade Nova de Lisboa), 2019, pp. 139-158.

De Epalza, Míkel y Rubiera, María Jesús, "La sofra (sujra) en el Sharq Al-Andalus antes de la conquista catalano-aragonesa", Sharq Al-Andalus, 3 (1986), pp. 33-38.

Eritja i Ciuró, Xavier, De l'Almunia a la Turris: organització de l'espai a la regió de Lleida (segles XI-XIII), Lleida, Universitat de Lleida, 1998.

Fahd, Toufic, "Traductions en arabe d'écrits géoponiques", en Expiración García Sánchez (ed.), Ciencias de la Naturaleza en al-Andalus. Textos y Estudios II, Granada, CSIC- Escuela de Estudios Árabes, 1992, pp. 11-21.

Fahd, Toufic, "L'agriculture nabatéenne en Andalousie", en Camilo Álvarez de Morales (ed.) Ciencias de la Naturaleza en al-Andalus. Textos y Estudios IV, Granada, CSIC- Escuela de Estudios Árabes, 1996, pp. 41-51.

El-Faïz, Mohammed, "Contribution du livre de l'agriculture nabatéenne à la formation de l'agronomie andalouse médiévale", en Expiración García Sánchez (ed.), Ciencias de la Naturaleza en al-Andalus. Textos y Estudios I, Granada, CSIC- Escuela de Estudios Árabes, 1990, pp. 163-177.

El-Faïz, Mohammed, 'L'apport des traités agronomiques hispanoarabes à l'histoire économique d'al-Andalus", en Expiración García Sánchez (ed.), Ciencias de la Naturaleza en al-Andalus. Textos y Estudios III, Granada, CSIC- Escuela de Estudios Árabes, 1994, pp. 403-433.

El-Faïz, Mohammed, “L'apport des agronomes d'al-Andalus à l'histoire de la pensée économique", en Camilo Álvarez de Morales (ed.), Ciencias de la Naturaleza en al-Andalus. Textos y Estudios IV, Granada, CSIC- Escuela de Estudios Árabes, 1996, pp. 53-70.

García Gómez, Emilio, "Sucursal del paraíso", $A B C, 28$ febrero de 1947,p. 3, [en línea], disponible en: $<$ http:// hemeroteca.abc.es/nav/Navigate.exe/hemeroteca/ madrid/abc/1947/02/28/003.html>, [consultado el 03/11/2019].

García Gómez, Emilio, Silla del Moro y nuevas escenas andaluzas, Madrid, 1948. 
García Gómez, Emilio, "Unas 'ordenanzas del zoco' del s. IX. Traducción del más antiguo antecedente de los tratados andaluces de hisba, por un autor andaluz", Al-Andalus, 22, 2 (1957), pp. 253-316.

García Sánchez, Expiración, "Problemática en torno a la autoría de algunas obras agronómicas andalusíes", en Homenaje al Prof. Dario Cabanelas Rodríguez, O.F.M., con motivo de su LXX aniversario, Granada, 1987, II, pp. 333-341.

García Sánchez, Expiración, “El tratado agrícola del granadino al-Tignarī”, Quaderni di Studi Arabi, $1987-$ 1988, vol. 5-6, pp. 278-291, [en línea], disponible en: $\quad<$ https://digital.csic.es/handle/10261/25377>, [consultado el 25/02/2020].

García Sánchez, Expiración, “Agricultura y legislación islámica: el prólogo del Kitāb Zuhrat al-bustān de al-Ṭignarī”, en Expiración García Sánchez (ed.), Ciencias de la Naturaleza en al-Andalus. Textos y Estudios I, Granada, 1990, pp. 179-193, [en línea], disponible en: <https:/digital.csic.es/ handle/10261/25590>, [consultado el 03/11/2019].

García Sánchez, Expiración, "La conservación de los productos vegetales en las fuentes agronómicas andalusíes", en Manuela Marín y David Waines (ed.), La alimentación en las culturas islámicas: una colección de estudios, Madrid, Agencia Española de Cooperación Internacional, 1994, pp. 251-293, [en línea], disponible en: <https:/digital.csic.es/ handle/10261/96191> [consultado el 03/11/2019].

García Sánchez, Expiración, “Cultivos y espacios agrícolas irrigados en al-Andalus", II Coloquio Historia y Medio Físico. Agricultura y regadio en al-Andalus, Almería, 1996, pp. 17-37, [en línea], disponible en: <https://dialnet.unirioja.es/servlet/articulo? codigo $=1226464>$, [consultado el 03/11/2019].

García Sánchez, Expiración, "Las fuentes citadas en el tratado agrícola de al-Ṭignarī”, Dynamis, 21 (2001), pp. 205-231, [en línea], disponible en: <https:// digital.csic.es/handle/10261/25733>, [consultado el 03/11/2019].

García Sánchez, Expiración, "Ibn al-`Awwām, Abū Zakarīyā",, en Jorge Lirola (dir.) y José Miguel Puerta Vílchez (ed. lit.), Biblioteca de al-Andalus, Almería, Fundación Ibn Tufayl de Estudios Árabes, 2009, vol. 2, pp. 447-451.

García Sánchez, Expiración, "al-Ṭignarī, Abū 'Abd Allāh”, en Jorge Lirola (dir.) y José Miguel Puerta Vílchez (ed. lit.), Biblioteca de al-Andalus, Almería, Fundación Ibn Tufayl de Estudios Árabes, 2012, vol. 7, pp. 454-459.

García Sánchez, Expiración, "Las huertas del Generalife en época islámica”, en J. Esteban Hernández Bermejo y Expiración García Sánchez (coords.), Las huertas del Generalife: paisajes agrícolas de
al-Andalus... en busca de la autenticidad, Granada, Editorial Comares, 2015, pp. 55-86.

García Sánchez, Expiración, "Terminología y funcionalidad de las almunias andalusíes a través de los textos agronómicos", en Julio Navarro Palazón y Carmen Trillo San José (eds.), Almunias. Las fincas de las elites en el Occidente islámico: poder, solaz y producción. Granada, Consejo Superior de Investigaciones Científicas, Patronato de la Alhambra y Generalife, Universidad de Sevilla, Universidad de Córdoba y Universidad de Granada, 2018, pp. 17-25.

Glick, Thomas, Islamic and Christian Spain in the Early Middle Ages, Princeton, University Press, 1979.

Guichard, Pierre, Al-Andalus. Estructura antropológica de una sociedad islámica en Occidente, Barcelona, Barral, 1976.

Guichard, Pierre, "Crecimiento urbano y sociedad rural en Valencia a principios de la época de los reinos de taifas (siglo XI después de J. C.). Traducción y comentario de un texto de Ibn Hayyān", Estudios sobre Historia Medieval, Valencia, Institució Valenciana d'Estudis i Investigació, 1987, pp. 153-174.

Guichard, Pierre, Les musulman de Valence et la Reconquête (XI'-XIII ${ }^{e}$ siècles), Damasco, Institut Français de Damas, 1990-91, 2 vols.

Guichard, Pierre, Al-Andalus frente a la conquista cristiana: los musulmanes de Valencia (siglos XI-XIII), Madrid, 2001.

Guichard, Pierre y Soravia, Bruna, Los reinos de taifas. Fragmentación política y esplendor cultural, Málaga, Editorial Sarriá, 2005.

Jiménez Castillo, Pedro, "La ciudad y el reino de Murcia durante el siglo XI", Cuando Almería era Almariyya, Almería, Instituto de Estudios Almerienses y Asociación Amigos de la Alcazaba, 2016, pp. 151204.

Jiménez Castillo, Pedro, "Fincas aristocráticas en la Murcia islámica: rahales, reales y torres", Аnuario de Estudios Medievales, 48, 2 (2018), pp. 749-791, [en línea], DOI: https://doi.org/10.3989/ aem.2018.48.2.08.

Jiménez Castillo, Pedro, "Reales y rahales de la Murcia andalusí: la penetración de las élites urbanas en el medio rural", en Julio Navarro Palazón y Carmen Trillo San José (ed.), Almunias. Las fincas de las elites en el Occidente islámico: poder, solaz y producción, Granada, CSIC, Patronato de la Alhambra y Generalife, Universidad de Sevilla, Universidad de Córdoba y Universidad de Granada, 2018, pp. 389-436.

Jiménez Castillo, Pedro, "La expansión agrícola en Šarq al-Andalus (ss. X-XII)”, Al-Qanțara, en prensa.

Jiménez Castillo, Pedro y Simón García, José Luis, "El poblamiento andalusí en las tierras de secano: 
el área sudoriental de La Mancha (ss. XI-XIII)", Al-Qantara, 38, 2 (2017), pp. 215-259.

Kautsky, John H., The Politics of Aristocratic Empires, Chapel Hill (NC), University of North Carolina Press, 1982.

Kazimirski, Albert de Biberstein, Dictionnaire arabe français, 2 vols., París, 1860.

Kirchner, Helena, "Huṣūn y alquerías campesinas en las Islas Orientales de al-Andalus", en Miquel Barceló y Pierre Toubert, "L'incastellamento» Actes des rencontres de Gérone (26-27 novembre 1992) et de Rome (5-7 mai 1994), Roma, École Française de Rome, 1998, pp. 249-269.

Kirchner, Helena, Virgili, Antoni y Antolín, Ferrán, "Un espacio de cultivo urbano en al-Andalus: Madîna Turțûša (Tortosa) antes de 1148”, Historia Agraria, 62 (2014), pp. 11-45.

Lagardère, Vincent, "Terres communes et droits d'usage en al-Andalus (Xe-XVe siècles)", Biens communs, patrimoines collectifs et gestión communautaire dans les sociétés musulmanes. Revue des Mondes Musulman et de la Méditerranée, 79-80 (1997), pp. 43-54.

Lenski, Gerhard, Poder y privilegio. Teoría de la estratificación social, Barcelona, Paidós, 1969.

Lirola Delgado, Jorge y García Sánchez, Expiración, "Ibn Luyūn", Biblioteca de al-Andalus, Almería, Fundación Ibn Tufayl de Estudios Árabes, 2006, vol. 4, pp. 41-49.

López y López, Ángel Custodio, “Ibn Bașṣāl, Abū Adbd al-Lāh”, en Jorge Lirola (dir.) y José Miguel Puerta Vílchez (ed. lit.), Biblioteca de al-Andalus, Almería, Fundación Ibn Tufayl de Estudios Árabes, 2009, vol. 2, pp. 565-573.

López y López, Ángel Custodio, "Ibn Abī 1-Ŷawād", en Jorge Lirola (dir.) y José Miguel Puerta Vílchez (ed. lit.), Biblioteca de al-Andalus, Almería, Fundación Ibn Tufayl de Estudios Árabes, 2012, vol. 1, pp. 753-755.

Malalana, Antonio y Morín de Pablos, Jorge, "La elaboración de compost en al-Andalus durante los siglos X-XI. Una reinterpretación del silo-basurero a partir de la arqueología", Actas RAM 2015. Reunión de Arqueología Madrileña 2015, Madrid, Sección de Arqueología del Colegio de Doctores y Licenciados en Filosofía y Letras y en Ciencias de Madrid, 2018, pp. 118-126.

Malpica Cuello, Antonio, "Formación y desarrollo del sistema irrigado en al-Andalus", Norba. Revista de Historia, 25-26 (2012-2013), pp. 41-60.

Manzano Martínez, José Antonio, “Aproximación a la estructura de la propiedad musulmana de la tierra en la huerta de Murcia (siglo XIII)", Actas del Coloquio CASTRUM 5. Archéologie des espaces agraires méditerranéens au Moyen Âge. Murcia 8-12 de mayo de 1992, Madrid-Roma-Murcia, École Française de Rome, 1999, pp. 61-75.

Manzano Martínez, José Antonio, “Aproximación a la problemática histórica de un espacio hidráulico: la huerta de Murcia", Memorias de Arqueología. 9. 1994, Murcia, Dirección General de Cultura, 1999, pp. 489-507.

Martí Castelló, Ramón, “Oriente y Occidente en las tradiciones hidráulicas medievales", en I Coloquio de Historia y Medio físico: el agua en zonas áridas. Arqueología e Historia. Hidráulica tradicional de la provincia de Almería. Coord. Lorenzo Cara Barrionuevo, Almería, 1989, II, pp. 419-440, [en línea], disponible en: <https://dialnet.unirioja.es/ servlet/articulo?codigo $=2244642>, \quad[$ consultado el 03/11/2019].

Mazzoli-Guintard, Christine, Villes d'al-Andalus. L'Espagne et le Portugal à l'époque musulmane (VIIIe-XVe siècles), Rennes, Presses Universitaires de Rennes, 1996.

Millás Vallicrosa, José María, "La traducción castellana del 'Tratado de Agricultura' de Ibn Wāfid", Al-Andalus, 8 (1943), pp. 281-332.

Molina López, Emilio, "Más sobre el mustajlaṣ”, Concepción Castillo Castillo, Imaculada Cortés Peña y Juan Pedro Monferrer Sala (eds.) Estudios árabes dedicados a D. Luis Seco de Lucena (en el XXV aniversario de su muerte), Granada, Universidad de Granada, 1999, pp. 107-118.

Münzer, Jerónimo, Viaje por España y Portugal (14941495), Madrid, Polifemo, 1991.

Navarro Palazón, Julio y Jiménez Castillo, Pedro, "Aproximación al estudio del Castillejo de Monteagudo y otros monumentos de su entorno", $\mathrm{Me}$ morias de Arqueología, 4, 1989, Murcia, Dirección General de Cultura, 1993, pp. 433-453.

Navarro Palazón, Julio y Jiménez Castillo, Pedro, Siyāsa: estudio arqueológico del despoblado andalusí (ss. XI-XIII), Granada, El Legado Andalusí, 2007.

Navarro Palazón, Julio y Jiménez Castillo, Pedro, “El Alcázar Menor de Murcia en el siglo XIII. Reconstrucción de una finca palatina andalusí”, La ciudad medieval: de la casa principal al palacio urbano. Toledo, 2011, pp. 145-188.

Navarro Palazón, Julio; Garrido Carretero, Fidel; Torres Carbonell, José Manuel y Triki, Hamid, “Agua, arquitectura y poder en una capital del Islam: la finca real del Agdal de Marrakech (ss. XII-XX)", Arqueología de la Arquitectura, 10 (2013), pp. 1-43.

Navarro Palazón, Julio y Garrido Carretero, Fidel, "El paisaje periurbano de Marrakech: la Menara y otras fincas de recreo (siglos XII-XX)", en Julio Navarro Palazón y Carmen Trillo San José (eds.), Almunias. 
Las fincas de las elites en el Occidente islámico: poder, solaz y producción. Granada, CSIC, Patronato de la Alhambra y Generalife, Universidad de Sevilla, Universidad de Córdoba y Universidad de Granada, 2018, pp. 195-284.

Navarro Palazón, Julio y Puerta Vílchez, José Miguel, "Las huertas de Marrakech en las fuentes escritas: bustān, buhayra, ŷanna, rawd y agdāl (siglos XIIXX)", en Julio Navarro Palazón y Carmen Trillo San José (eds.), Almunias. Las fincas de las elites en el Occidente islámico: poder, solaz y producción. Granada, CSIC, Patronato de la Alhambra y Generalife, Universidad de Sevilla, Universidad de Córdoba y Universidad de Granada, 2018, pp. 285-306.

Navarro Palazón, Julio, Garrido, Fidel y Almela, Íñigo, "The Agdal of Marrakesh (12th to 20th Centuries): An Agricultural Space for Caliphs and Sultans. Part II: Hydraulics, Architecture and Agriculture", $\mathrm{Mu}$ qarnas, 35 (2018), pp. 1-64.

Orihuela Uzal, Antonio y García Pulido, Luis J., "El suministro de agua en la Granada islámica", Ars mechanicae: ingeniería medieval en España: [exposición] / Marta Grau Fernández (aut.), 2008, pp. 143-150.

Pocklington, Robert, La Casida Macsura de Házim al-Cartayánni (Descripción de Murcia y Cartagena). Discurso de recepción en la Real Academia Alfonso X el Sabio, Murcia, 2018.

Del Pulgar, Hernando, Crónica de los señores Reyes Católicos don Fernando y doña Isabel de Castilla y Aragón, Valencia, Imprenta de Benito Monfort, 1780.

Quirós García, Mariano, "El Libro de Agricultu$r a$ de Gabriel Alonso de Herrera: un texto en busca de edición", Criticón 123 (2015), [en línea], disponible en: <https://journals.openedition.org/ criticon/1540>,DOI:https://doi.org/10.4000/criticon .1540. [consultado el 03/02/2020].

Ramón-Laca Menéndez de Luarca, Luis, “Almunias en los reinos de Castilla y Aragón según la documentación medieval (siglos XI-XIII)", en Julio Navarro Palazón y Carmen Trillo San José (eds.), Almunias. Las fincas de las elites en el Occidente islámico: poder, solaz y producción. Granada, Consejo Superior de Investigaciones Científicas, Patronato de la Alhambra y Generalife, Universidad de Sevilla, Universidad de Córdoba y Universidad de Granada, 2018, pp. 443-451.

Retamero Serralvo, Félix, "De Mulk a Mulūk: un conjunto de reglas sabias y ordenadas: la disciplina agraria del sulțān", en Carlos Laliena y Juan F. Utrilla (eds.), De Toledo a Huesca. Sociedades medievales en transición a finales del siglo XI (10801100), Zaragoza, 1998, pp. 75-91.

Retamero Serralvo, Félix, "La sombra alargada de Wittfogel. Irrigación y poder en al-Andalus", en Manuela Marín (ed.), Al-Andalus/España. Historiografias en contraste. Siglos XVII-XXI, Collection de la Casa de Velázquez (109), Madrid, 2009, pp. 263-293.

Salvatierra, Vicente y Gómez, Francisco, "La presa de la Garganta del Ciervo, s. XII (Segura de la Sierra, Jaén, España): aportaciones a la ingeniería hidráulica andalusí", Lvcentvm, 35 (2016), pp. 307-322.

Sénac, Philippe, “De la madîna à l'almunia. Quelques réflexions autour du peuplement musulman au nord de l'Ebre", Annales du Midi: revue de la France méridionale, 278 (2012), pp. 183-201.

Tahiri, Ahmed, Las clases populares en al-Andalus, Málaga, Sarriá, 2003.

Terrón, Eloy, "La experiencia derivada de la práctica agropecuaria, base de todo conocimiento", en Gabriel Alonso de Herrera, Agricultura general, Madrid, Ministerio de Agricultura y Pesca, 1981, pp. 3-37.

Trabelsi, Bouraoui, "Les origines de l'agronomie andalouse: nouveaux arguments en faveur d'une filiation orientale", Revue d'Histoire Maghrébine, 125 (2007), pp. 131-149.

Trillo San José, Carmen, Agua, tierra y hombres en al-Andalus, Granada, Grupo de Investigación "Toponimia, Historia y Arqueología del Reino de Granada", 2004.

Valor Piechotta, Magdalena y Jiménez Hernández, Alejandro, "Las almunias de la Sevilla almohade: Buhayra y Aznalfarache", en Julio Navarro Palazón y Carmen Trillo San José (eds.), Almunias. Las fincas de las elites en el Occidente islámico: poder, solaz y producción, Granada, Consejo Superior de Investigaciones Científicas, Patronato de la Alhambra y Generalife, Universidad de Sevilla, Universidad de Córdoba y Universidad de Granada, 2018, pp. 323-342.

Vidal Castro, Francisco, "La musāqāt: Un contrato de riego en la agricultura de al-Andalus y el Magreb. Teoría y práctica jurídicas", II Coloquio Historia y Medio Físico. Agricultura y regadio en al-Andalus, Almería, 1996, pp. 429-451, [en línea], disponible en: $<$ http://www4.ujaen.es/ fvidal/pdf-s/Vidal-La\%20 musaqa.pdf $>$, [consultado el 03/11/2019].

Watson, Andrew M., Innovaciones en la agricultura en los primeros tiempos del mundo islámico: difusión de los distintos cultivos y técnicas agrícolas, del año 700 al 1100, Granada, Universidad, 1998. 